\title{
Late-stage magmatic to deuteric/metasomatic accessory minerals from the Cerro Boggiani agpaitic complex (Alto Paraguay Alkaline Province)
}

\author{
Piero Comin-Chiaramonti ${ }^{\mathrm{a}, * *}$, Alberto Renzulli ${ }^{\mathrm{b}, *}$, Filippo Ridolfi ${ }^{\mathrm{b}}$, Gaston E.R. Enrich ${ }^{\mathrm{c}}$, Celso B. Gomes ${ }^{\mathrm{c}}$, \\ Angelo De Min ${ }^{\text {a }}$, Rogério G. Azzone ${ }^{\mathrm{c}}$, Excelso Ruberti ${ }^{\mathrm{c}}$ \\ a Dipartimento di Matematica e Geoscienze, University of Trieste, Via Weiss 8, I-34127 Trieste, Italy \\ b Dipartimento di Scienze Pure e Applicate, University of Urbino, Campus Scientifico "Enrico Mattei”, Via Cà Le Suore 2-4, 61029 Urbino, Italy \\ ${ }^{c}$ Instituto de Geociências, University of São Paulo, Cidade Universitária, Rua do Lago 562, 05508-080 São Paulo, Brazil
}

\section{A R T I C L E I N F O}

Article history:

Received 24 March 2016

Received in revised form 22 July 2016

Accepted 8 August 2016

Available online $\mathrm{xxx}$

Keywords:

REE-bearing minerals

Carbonates

Zirconosilicates

Peralkaline

Agpaitic

Deuteric

Metasomatic

Carbonatitic fluids

Cerro Boggiani

Paraguay

\begin{abstract}
A B S T R A C T
This work describes rare accessory minerals in volcanic and subvolcanic silica-undersaturated peralkaline and agpaitic rocks from the Permo-Triassic Cerro Boggiani complex (Eastern Paraguay) in the Alto Paraguay Alkaline Province. These accessory phases consist of various minerals including Th-U oxides/silicates, Nb-oxide, REE-Sr-Ba bearing carbonates-fluorcarbonates-phosphates-silicates and $\mathrm{Zr}-\mathrm{Na}$ rich silicates. They form a late-stage magmatic to deuteric/ metasomatic assemblage in agpaitic nepheline syenites and phonolite dykes/lava flows made of sodalite, analcime, albite, fluorite, calcite, ilmenite-pyrophanite, titanite and zircon. It is inferred that carbonatitic fluids rich in F, Na and REE percolated into the subvolcanic system and metasomatically interacted with the Cerro Boggiani peralkaline and agpaitic silicate melts at the thermal boundary layers of the magma chamber, during and shortly after their late-stage magmatic crystallization and hydrothermal deuteric alteration.
\end{abstract}

(C) 2016 Published by Elsevier Ltd.

\section{Introduction}

Accessory minerals of the silica-undersaturated peralkaline Cerro Boggiani complex, at the border of Brazil and Paraguay have been studied in detail within the framework of a collaborative scientific program involving researchers from Brazil and Italy.

The rock types are agpaitic nepheline syenites and phonolites composed of alkali feldspar (52-60 vol\%), nepheline (15-28 vol\%), locally abundant sodalite $(8-17 \mathrm{vol} \%)$, sodic clinopyroxene (4-16 vol\%), scarce biotite (annite-rich: $0.2-0.5$ vol\%) and amphibole (katophorite-richterite: $0.2-0.9$ vol\%; cf. Tab. 34 of Comin-Chiaramonti et al., 2005) with primary accessories (titanite, magnetite, ilmenite, zircon and aenigmatite), and a wide range of very late-crystallized phases which are often difficult to analyse quantitatively owing to their small size or their volatile nature under the electron beam. Minerals identified so far include ancylite, bastnäsite-parisite-synchysite, britholite, burbankite, cordylite, eudialyte (subordinately Ca-catapleiite), låvenite, pyrochlore, rosenbuschite, thorite and uraninite-thorianite, usually related to late-stage magmatic crystallization, deuteric and/or metasomatic fluids

\footnotetext{
* Corresponding author.

** Corresponding author.

Email address: alberto.renzulli@uniurb.it (A. Renzulli)
}

(Castorina et al., 1997; Enrich et al., 2010, 2011, 2012) enriched in rare earth elements, fluorine, chlorine, $\mathrm{H}_{2} \mathrm{O}$ and $\mathrm{CO}_{2}$.

This paper reports the composition and textural relationships of these accessory minerals (see also Comin-Chiaramonti et al., 2005, Carbonin et al., 2005; Enrich et al., 2010, 2011, 2012), which are generally very similar to those found in other peralkaline rocks worldwide (e.g. Junguni intrusion, Malawi, after Woolley and Platt, 1988; Agua de Pau Volcano, Azores, after Ridolfi et al., 2003; Kilombe Volcano, Kenia, after Ridolfi et al., 2006). A sequence of crystallization of the investigated accessory minerals is also emphasized.

\section{Geological background}

In the Alto Paraguay Province (APP), alkaline magmatism occurs along the Paraguay River (Fig. 1). It consists of a series of stocks and ring complexes cropping out along both riverbanks, mainly to the north and south of Porto Murtinho city in the Mato Grosso do Sul State, Brazil. Radiometric ages of this magmatic activity have recently been reviewed by Comin-Chiaramonti et al. (2015 and references therein). The average $\mathrm{K} / \mathrm{Ar}$ and $\mathrm{Ar} / \mathrm{Ar}$ ages were determined as $248.8 \pm 4.8 \mathrm{Ma}$ and $241.8 \pm 1.1 \mathrm{Ma}$, while best values of $\mathrm{Rb} / \mathrm{Sr}$ and $\mathrm{Sm} / \mathrm{Nd}$ isochrons point to ages of $244 \pm 27 \mathrm{Ma}$ and $256 \pm 3$ to $257 \pm 3 \mathrm{Ma}$, respectively. These ages show that the complexes were 


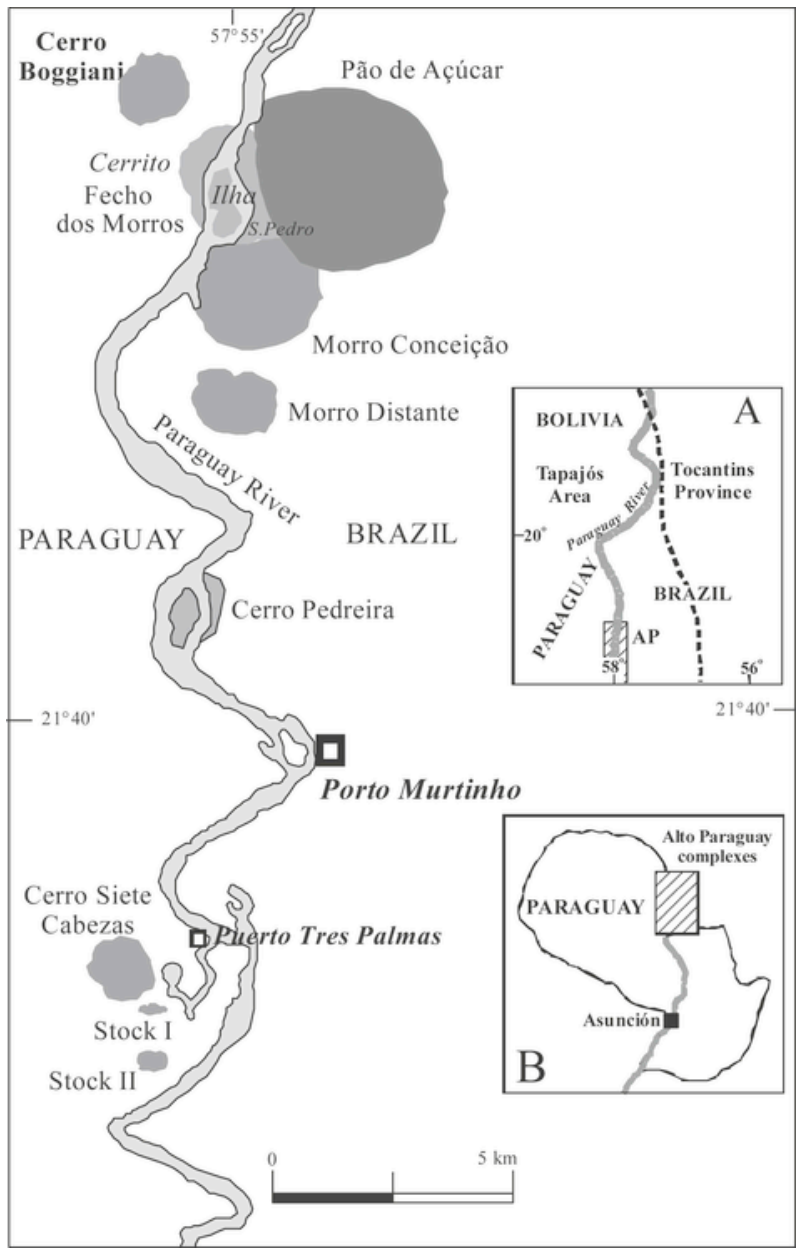

Fig. 1. Sketch map showing the main alkaline igneous rock occurrences of the Alto Paraguay Alkaline Province (Comin Chiaramonti et al., 2005 and references therein). Inset A: Map representing the Tocantíns Neoproterozoic orogenic area (Madeiro subprovince, after Amaral, 1984; Soares et al., 2006) and the adjacent Paleoproterozoic Tapajos Province (Lemarão et al., 2002) separated by a bold, dotted line. AP: Alto Paraguay alkaline complexes. Inset B: position of the Alto Paraguay alkaline complexes within Paraguay.

emplaced during the Early Triassic and represent the oldest magmatic activity around the Paraná Basin, tectonically related to the Tapajós and Tocantins Provinces, after the Brasiliano cycle (Comin-Chiaramonti et al., 2015 and references therein).

APP consists of seven major circular complexes (from north to south: Cerro Boggiani, Pão de Açúcar, Fecho dos Morros, Morro Conceição, Morro Distante, Cerro Pedreira and Cerro Siete Cabezas) and some minor stocks, lava flows and dykes (Fig. 1). Intrusive to subvolcanic rocks are mostly sodic in composition and mainly represented by nepheline syenites, syenites, quartz-bearing syenites and their corresponding extrusive rock types (i.e. phonolites and trachytes). Miaskitic (slightly agpaitic, with rare minerals having alkalinity modulus, $\mathrm{K}_{\text {alk }}$, 15 as defined by Khomyakov, 1995) and agpaitic (with rare minerals with $\mathrm{K}_{\text {alk }}=15-40$ ) suites characterize the southern (Cerro Siete Cabezas) and northern (Cerro Boggiani, Pão de Açúcar, Fecho dos Morros-Cerrito) occurrences, respectively (Comin-Chiaramonti et al., 2014). It is worth to note the term agpaitic should be restricted to peralkaline nepheline syenites and phonolites containing complex silicate minerals of $\mathrm{Zr}$, Ti, REEs, fluorine and other volatiles (such as eudialyte, Sørensen, 1997). In this way, the Cerro Boggiani nepheline normative rocks having a peralkaline index (also referred to as agpaitic index, A.I.) between 1.1 and 1.5 (Gomes et al., 1996; cf. Tab. 35 of Comin-Chiaramonti et al., 2005) and also containing the above complex silicate minerals (with $\mathrm{K}_{\mathrm{alk}}$ 15-40), can be considered agpaitic stricto sensu. Cerro Boggiani consists of a small hill, $0.5 \mathrm{~km}$ in diameter and $<140 \mathrm{~m}$ high, associated with two satellite plugs and dykes cropping out above the alluvial sediments of the Paraguay river (Putzer and Van den Bomm, 1962). Overall, the intrusions seem to define a circular structure extending over $4 \mathrm{~km}^{2}$ (Comin-Chiaramonti et al., 2005).

\section{Petrography and chemical features}

Cerro Boggiani intrusive complex $\left(21^{\circ} 24^{\prime} 00^{\prime \prime} \mathrm{S}\right.$ and $\left.57^{\circ} 56^{\prime} 50^{\prime \prime}\right)$ is located ca. $2.5 \mathrm{~km} \mathrm{NW}$ of the Pão de Açúcar volcanic centre (Fig. 1) and consists mainly of foid syenites and nepheline syenites with modal nepheline and sodalite contents of $16-28$ and $8-17 \mathrm{vol} \%$, respectively. The lithotypes are medium to coarse-grained and allotriomorphic in texture, and contain abundant perthitic alkali feldspar (up to $60 \mathrm{vol} \%$ ). They also have clinopyroxene (aegirine-augite to aegirine, up to $8 \mathrm{vol} \%$ ) as the most abundant mafic phase, and amphibole (ferrorichterite to arfvedsonite, $0.2-0.9 \mathrm{vol} \%$ ) partially replacing the former at the rims ( \pm biotite) and accessory phases such as ilmenite-pyrophanite, titanite and apatite. In addition, late-stage magmatic to deuteric/metasomatic accessory minerals, such as aenigmatite, ancylite, bastnäsite-parisite-synchysite, britholite, burbankite, Ca-catapleiite, eudialyte, låvenite, pyrochlore, rosenbuschite, thorite, uraninite-thorianite and carbonates, occur locally. Carbonates, cancrinite and zeolites usually point out the post-magmatic conditions of crystallization (Fig. 2).

On the other hand, extrusive rocks (lava flows and dikes) cluster in the phonolite field (Fig. 3A). They are characterized by an aphanitic groundmass with phenocryst and/or microphenocryst of alkali feldspar, nepheline (up to $20 \mathrm{vol} \%$ ), sodalite and subordinate aegirine-augite, sodic amphibole, aenigmatite and biotite set in a very fine trachytoidal matrix. Main accessory phases are apatite, eudialyte, låvenite, pyrophanite, rosenbuschite, titanite and uraninite; carbonates can be also present as patches and/or veins (Comin-Chiaramonti et al., 2005). Deuteric and metasomatic conditions of crystallization (Stoppa and Schiazza, 2014) are emphasized by the presence of cancrinite and zeolites.

The primary mineralogical assemblages indicate emplacement temperatures of $700-1000{ }^{\circ} \mathrm{C}$ and, for intrusive rock-types, a very low total pressure, i.e. around $1 \mathrm{~kb}$, with high fluorine activity. By contrast, the association of aenigmatite, ilmenite and annite-rich biotite suggests subsolidus reactions developing at the intersection of Ac-Ilm-Aen buffer with the Na-amphibole and annite stability field (cf. Nicholls and Carmichael, 1969) at temperatures around 500-570 ${ }^{\circ} \mathrm{C}$ (cf. Comin-Chiaramonti et al., 2005).

An Agpaitic (Peralkaline) Index (A.I.) vs. Quartz/Nepheline (Q-Ne) normative diagram (Fig. 3) shows that both intrusive and extrusive rocks from Cerro Boggiani have a strong peralkaline character, with A.I. as high as 1.5 (cf. Table 35 of Comin-Chiaramonti et al., 2005). Modal content of accessory phases averages $2.6 \pm 0.9 \mathrm{vol} \%$. Compositions of four representative samples, three phonolites (RP28, RP31A, RP41) and one nepheline syenite (RP38B), are reported in Table 1. Whole-rock spider diagrams of incompatible elements (Fig. 4) show positive anomalies of $\mathrm{U}-\mathrm{Th}, \mathrm{Nb}-\mathrm{Ta}, \mathrm{La}-\mathrm{Ce}-\mathrm{Nd}$ and $\mathrm{Zr}-\mathrm{Hf}$, which are related to both the alkaline affinity and the mineral chemistry of late-stage magmatic to deuteric and/or metasomatic accessory phases.

The isotopic $\mathrm{C}-\mathrm{O}$ values $(\delta \%$ ) in calcite of additional samples are reported in Table 2. It should be noted that these samples contain 

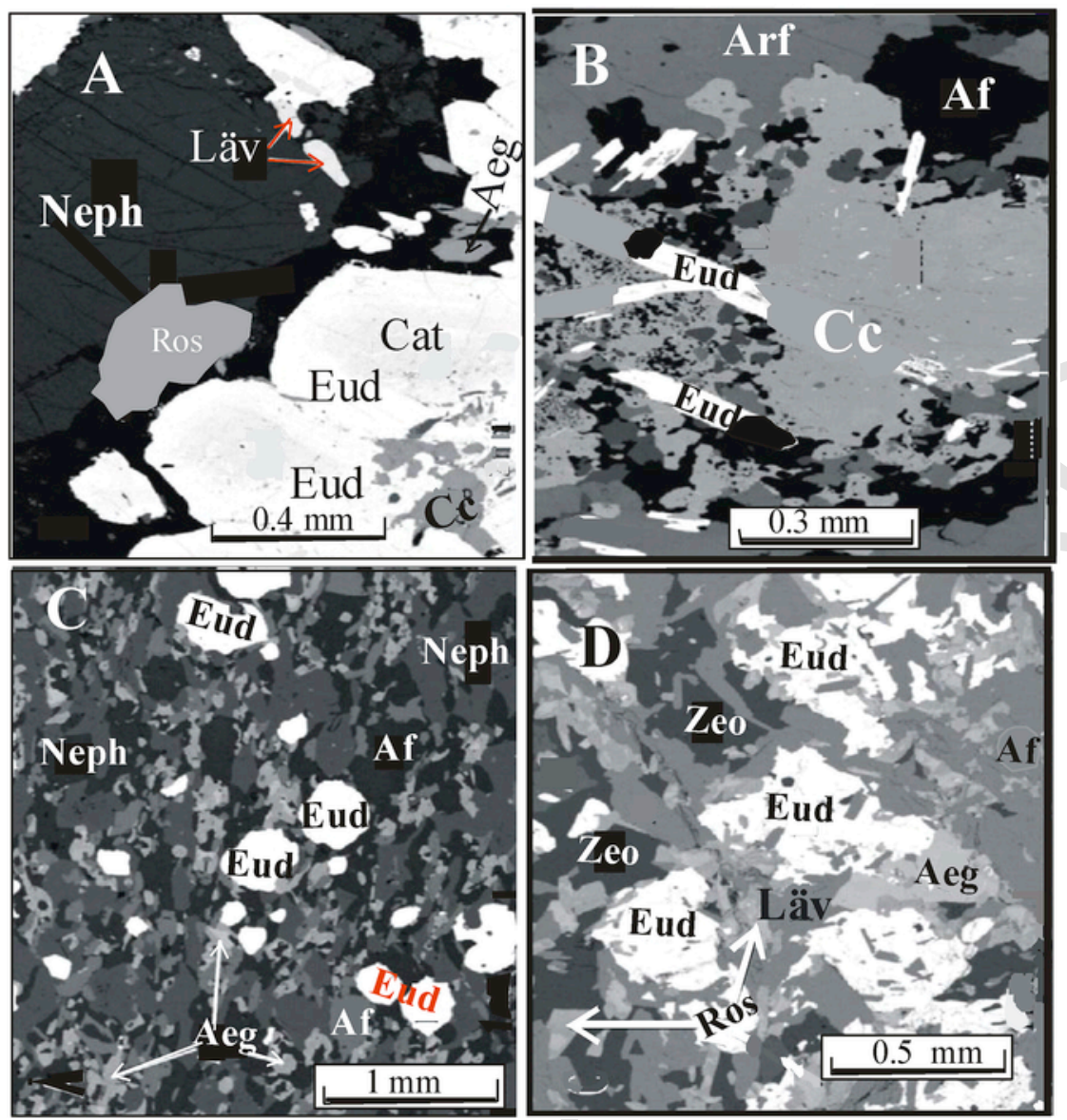

Fig. 2. Back-scattered Scanning Electron Microscope (SEM) images of fundamental and accessory minerals from the Cerro Boggiani agpaitic alkaline igneous rocks. A: large eudialyte (Eud) from nepheline syenite (RP33B) with catapleiite (Cat), nepheline (Neph), calcite (Cc), rosenbuschite (Ros) and låvenite (Låv); B: nepheline syenite (RP33B) showing eudialyte (Eud), arfvedsonite (Arf), calcite (Cc) and alkali feldspar (Af); C: fine grained eudialyte (Eud) in phonolitic lava flow (RP31A) associated with nepheline (Neph), alkali feldspar (Af) and aegirine (Aeg); D: eudialyte in nepheline syenite (RP33B), with zeolites (Zeo), aegirine (Aeg), alkali feldspar (Af) and rosenbuschite (Ros).

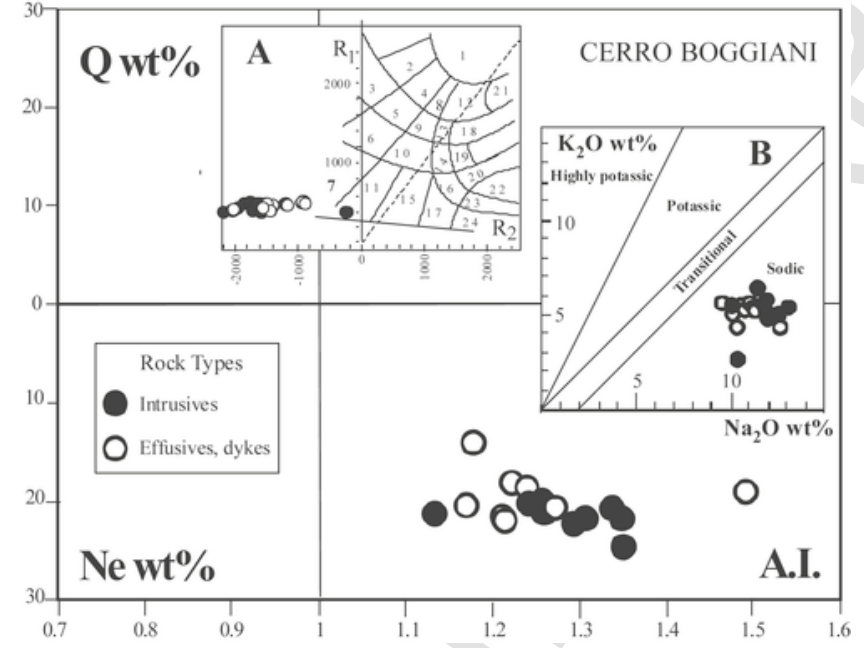

Fig. 3. Cerro Boggiani complex (data from Comin-Chiaramonti et al., 2005): agpaitic index [A.I. $=\left(\mathrm{Na}_{2} \mathrm{O}+\mathrm{K}_{2} \mathrm{O}\right) / \mathrm{Al}_{2} \mathrm{O}_{3}$, molar ratio] vs. normative quartz $(\mathrm{Q})$ and nepheline $(\mathrm{Ne})$ for sodic rock-types. Inset $\mathbf{A}: \mathrm{R}_{1}-\mathrm{R}_{2}$ classification diagram according to $\mathrm{De} \mathrm{La}$ Roche et al. (1980) showing field7, i.e. nepheline syenite-phonolite. Inset $\mathbf{B}: \mathrm{Na}_{2} \mathrm{O}$ vs. $\mathrm{K}_{2} \mathrm{O}$ wt $\%$ diagram (after Le Maitre, 1989) displaying the sodic field occupied by the Cerro Boggiani samples.
0.46-0.96 wt $\%$ of $\mathrm{CO}_{2}$, corresponding to $\mathrm{CaCO}_{3}$ equivalent contents of $1.00-2.18 \mathrm{wt} \%$. Table 2 shows that the average $\mathrm{CO}_{2} / \mathrm{H}_{2} \mathrm{O}$ ratio is $0.84 \pm 0.03$. Notably, this ratio and the isotopic $\mathrm{C}-\mathrm{O}$ values are representative of a hydrothermal environment (Fig. 5), as also indicated by curve I of the Cerro Chiriguelo wells (cf. also Fig. 8 of Comin-Chiaramonti et al., 2014).

The following paragraphs will describe the rare accessory minerals of Cerro Boggiani, roughly corresponding to the positive anomalies in the whole-rock incompatible elements, i.e. thorianite-uraninite-thorite (U, Th), pyrochlore $(\mathrm{Nb}), \mathrm{REE}$ minerals, rosenbuschite, låvenite, eudialyte $(\mathrm{Zr}-\mathrm{Hf})$.

\section{Analytical methods}

Modal mineralogy and mineral chemistry of the main phases (i.e. clinopyroxene, amphibole, aenigmatite, biotite, mesoperthite, sodic sanidine, nepheline, sodalite and ilmenite) from the Cerro Boggiani alkaline complexes are described in Comin-Chiaramonti et al. (2005). Accordingly, only the rare accessory phases are discussed here.

Quantitative analyses were performed on carbon-coated thin sections by wavelength dispersion method (WDS) at Padova (Italy) and São Paulo (Brazil) universities. In Padova (Institute of Geosciences and Georesources, CNR), the analyses were performed using a Cameca/Camebax electron microprobe with accelerating voltage and beam current ranging between 15 and $20 \mathrm{kV}$ and $10-20 \mathrm{n} \AA$, respec- 
Table 1

Representative whole-rock compositions of the Cerro Boggiani alkaline complex (major and trace elements are from Tables 35 and 40 of Comin-Chiaramonti et al., 2005). REE, Th, U, Hf and Ta were analysed by ICP-MS -Perkin Elmer Elan 5000 in a solution obtained by mixed $\mathrm{HF}^{-} \mathrm{HClO}_{4}$ digestion in sealed and pressurized Teflon vessels, following procedures outlined by Alaimo and Censi (1992). R1 and R2 classification following De La Roche et al., 1980; A.I., agpaitic index $\left(\mathrm{Na}_{2} \mathrm{O}+\mathrm{K}_{2} \mathrm{O} / \mathrm{Al}_{2} \mathrm{O}_{3}\right.$ molar ratio).

\begin{tabular}{|c|c|c|c|c|}
\hline $\begin{array}{l}\text { Major } \\
\text { elements }\end{array}$ & RP28 dyke & $\begin{array}{l}\text { RP31A lava } \\
\text { flow }\end{array}$ & $\begin{array}{l}\text { RP38B } \\
\text { intrusive rock }\end{array}$ & $\begin{array}{l}\text { RP41 lava } \\
\text { flow }\end{array}$ \\
\hline $\begin{array}{l}\text { Major } \\
\text { elements } \\
(w t \%)\end{array}$ & Phonolite & Phonolite & $\begin{array}{l}\text { Nepheline } \\
\text { syenite }\end{array}$ & Phonolite \\
\hline $\mathrm{SiO}_{2}$ & 57.83 & 57.46 & 57.57 & 57.01 \\
\hline $\mathrm{TiO}_{2}$ & 0.35 & 0.51 & 0.18 & 0.23 \\
\hline $\mathrm{Al}_{2} \mathrm{O}_{3}$ & 19.42 & 18.86 & 19.07 & 18.90 \\
\hline FeOtot & 2.33 & 3.14 & 4.60 & 4.68 \\
\hline $\mathrm{MnO}$ & 0.14 & 0.22 & 0.21 & 0.25 \\
\hline $\mathrm{MgO}$ & 0.10 & 0.26 & 0.05 & 0.07 \\
\hline $\mathrm{CaO}$ & 0.96 & 1.33 & 1.18 & 1.06 \\
\hline $\mathrm{Na}_{2} \mathrm{O}$ & 11.98 & 11.41 & 10.15 & 10.82 \\
\hline $\mathrm{K}_{2} \mathrm{O}$ & 5.83 & 5.46 & 5.59 & 5.55 \\
\hline $\mathrm{P}_{2} \mathrm{O}_{5}$ & 0.02 & 0.14 & 0.09 & 0.01 \\
\hline $\mathrm{H}_{2} \mathrm{O}^{+}$ & 0.55 & 0.92 & 1.10 & 0.88 \\
\hline $\mathrm{CO}_{2}$ & 0.46 & 0.81 & 0.96 & 0.73 \\
\hline Sum & 99.97 & 100.52 & 100.75 & 100.19 \\
\hline $\mathrm{R}_{1}$ & -1838 & -1600 & -1276 & -1478 \\
\hline $\mathrm{R}_{2}$ & 489 & 524 & 502 & 488 \\
\hline A.I. & 1.34 & 1.31 & 1.19 & 1.26 \\
\hline \multicolumn{5}{|c|}{ Trace elements (ppm) } \\
\hline $\mathrm{Ba}$ & 100 & 437 & 135 & 13 \\
\hline $\mathrm{Rb}$ & 247 & 243 & 291 & 354 \\
\hline $\mathrm{U}$ & 12.1 & 17.01 & 14.3 & 1.80 \\
\hline Th & 3.9 & 11.53 & 10.1 & 5.6 \\
\hline $\mathrm{Nb}$ & 149 & 237 & 128 & 186 \\
\hline $\mathrm{Ta}$ & 19.4 & 16.09 & 16.62 & 17.0 \\
\hline $\mathrm{La}$ & 139 & 137 & 96 & 54.0 \\
\hline $\mathrm{Ce}$ & 204 & 225 & 143 & 71.9 \\
\hline $\mathrm{Sr}$ & 133 & 319 & 104 & 72 \\
\hline $\mathrm{Nd}$ & 46 & 59 & 33 & 11.3 \\
\hline $\mathrm{Sm}$ & 5.81 & 6.79 & 4.75 & 1.5 \\
\hline $\mathrm{Zr}$ & 1696 & 1499 & 1670 & 2239 \\
\hline Hf & 33.10 & 33.75 & 34.73 & 70.3 \\
\hline $\mathrm{Tb}$ & 0.97 & 1.03 & 0.67 & 0.30 \\
\hline $\mathrm{Y}$ & 34 & 55 & 33 & 23.3 \\
\hline $\mathrm{Tm}$ & 0.85 & 1.16 & 0.70 & 0.50 \\
\hline $\mathrm{Yb}$ & 5.76 & 5.72 & 4.70 & 4.30 \\
\hline
\end{tabular}

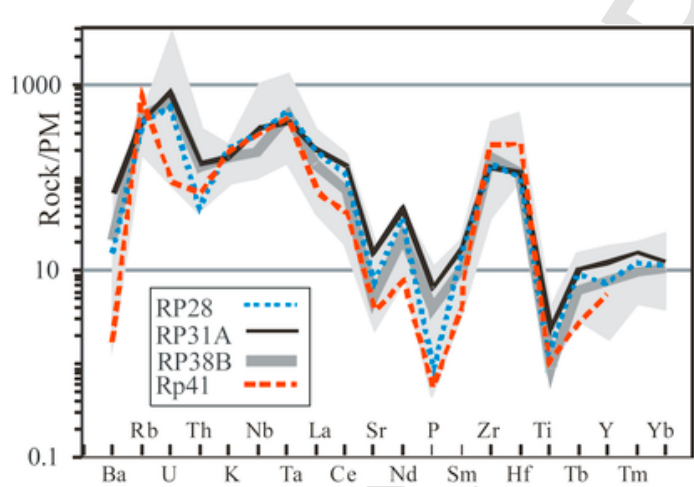

Fig. 4. Spider diagrams (PM, according to Sun and McDonough, 1989) for representative samples of Cerro Boggiani (RP28, phonolite dyke; RP31A, phonolite lava flow; RP38B, nepheline syenite; RP41, phonolite lava flow) normalized to primitive mantle. Grey field represents the general variation for all the Cerro Boggiani samples (cf. data of Tables 35 and 40, and Fig. 43 of Comin-Chiaramonti et al., 2005).
Table 2

Measured isotope compositions of carbonate fractions of alkaline rocks at Cerro Boggiani. $\mathrm{C}-\mathrm{O}$ isotopic values $(\delta \%$ ) were determined on the carbonate fractions according to Censi et al. (1989): the oxygen and carbon data of carbonate fractions from selected whole rocks were obtained by reacting the samples with $100 \% \mathrm{H}_{3} \mathrm{PO}_{4}$ at $25{ }^{\circ} \mathrm{C}$. The $\mathrm{CO}_{2}$ released was subsequently analysed in a Finnigan Mat Delta $\mathrm{S}$ mass spectrometer and its oxygen isotopic composition corrected to calcite by a fractionation factor of 1.01025 (cf. Speziale et al., 1997 and references therein). The powder sample prepared with grain size ranging between 100 and 200 mesh and the $\mathrm{CO}_{2}$ corresponding to calcite was extracted $1 \mathrm{~h}$ after reaction. The isotopic results are given in terms of usual $\delta \%$, the reference standards being PDB-1 and V-SMOW for carbon and oxygen isotopes, respectively.

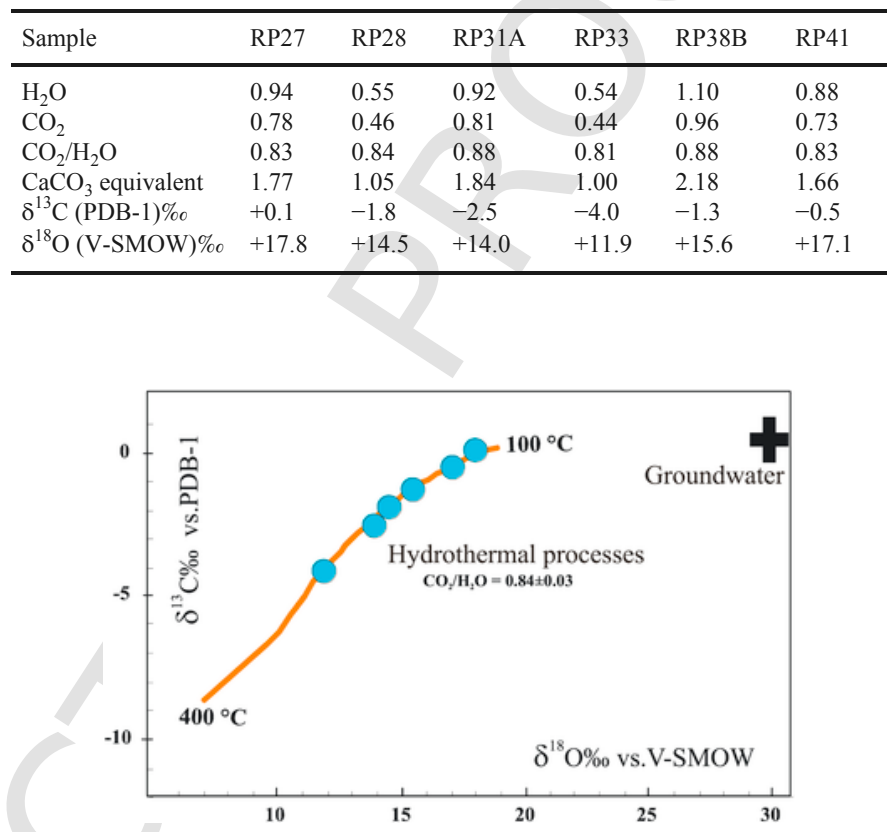

Fig. 5. Plot of $\delta^{18} \mathrm{O}$ vs. $\delta^{13} \mathrm{C}$ for carbonates from Cerro Boggiani (cf. Table 2) and evolution of the oxygen-carbon isotope composition in a hydrothermal environment, i.e. 400-100 ${ }^{\circ} \mathrm{C}$, according to Castorina et al. (1997) and Comin-Chiaramonti et al. (2005). Arbitrary composition of groundwater: $\delta^{18} \mathrm{O}=30 \%$ o, $\delta^{13} \mathrm{C}=0$ (after Taylor, 1978 and Usdowski, 1982).

tively (depending on the phase stability). X-ray counts were converted into oxide mass percentages by a PAP correction program provided by Cameca Minerals (Carbonin et al., 2005). In São Paulo (Instituto de Geociências), the analytical work was performed employing a Jeol JXA 8600 electron microprobe equipped with a Voyager Noran automation system. Analytical conditions for BSE imaging, quantitative WDS and qualitative EDS analyses were $15 \mathrm{kV}$ for accelerating voltage and $20 \mathrm{nA}$ for electron beam current. The data were processed utilizing the PROZA procedure (Bastin et al., 1984). In both laboratories, special care was taken in selecting peak and background positions in order to eliminate peak overlapping. Peak counting times were 10-20 s for F, Na, Mg, Al, Si, P, Cl, S, K, Ca, Fe, Mn, and Ti, and 60 s for the other elements. Natural minerals and synthetic materials were used as standards: $\mathrm{ThSiO}_{4}(\mathrm{Si} K \alpha), \mathrm{TiO}_{2}(\mathrm{Ti} K \alpha)$, zircon $(\mathrm{Zr} L \alpha), \mathrm{HfSiO}_{4}$ $(\mathrm{Hf} L \alpha), \mathrm{Nb}(\mathrm{Nb} L \alpha)$, Ta $(\mathrm{Ta} L \alpha)$, plagioclase $\mathrm{An}_{50}(\mathrm{Al} K \alpha)$, Y-garnet (YL $\alpha$ ), synthetic $\mathrm{Ca}-\mathrm{Al}$-silicate glasses $(\mathrm{La} L \alpha, \operatorname{Ce} L \alpha, \operatorname{Pr} L \beta, \operatorname{Nd} L \alpha$, $\operatorname{Sm} L \alpha, \operatorname{Gd} L \beta, \operatorname{Er} L \alpha, \operatorname{Yb} L \alpha)$, Mn-hortonolite $(\operatorname{Mn} K \alpha, \operatorname{Fe} K \alpha)$, diopside $(\mathrm{Mg} K \alpha)$, wollastonite $(\mathrm{Ca} K \alpha), \mathrm{Pb}(\mathrm{Pb} M \alpha)$, Amelia albite $(\mathrm{Na} K \alpha)$, Asbe K-feldspar $(\mathrm{K} K \alpha), \mathrm{CaF}_{2}(\mathrm{~F} K \alpha)$ and $\mathrm{Cl}$ apatite $(\mathrm{Cl} K \alpha)$ (cf. Drake and Weill, 1972; Roeder, 1985; Jarosevich, 2002). 


\section{Rare accessory minerals}

\subsection{U-Th-bearing minerals (uraninite-thorianite, thorite)}

$\mathrm{U}$ - Th minerals are represented by uraninite-thorianite $\left(\mathrm{UO}_{2}-\right.$ $\mathrm{ThO}_{2}$ ) and thorite (Th, $\mathrm{U} \mathrm{SiO}_{4}$; Table 3), ranging in size from 1 to $10 \mu \mathrm{m}$. SEM images are shown in supplementary materials (S1 and S2).

Thorianite has $\mathrm{ThO}_{2}$ contents from 65 to $87 \mathrm{wt} \%$, whereas $\mathrm{UO}_{2}$ in uraninite grains varies between 83 and $89 \mathrm{wt} \%$ (Fig. 6A). Thorite, a rare nesosilicate of thorium that crystallizes in the tetragonal system, on the other hand, is isomorphous with zircon and contains high $\mathrm{ThO}_{2}$ (from 43 to $55 \%$ ) and low $\mathrm{UO}_{2}(1.6-2.3 \%$ ) contents. Yttrium

Table 3

Representative analyses of uraninite, thorianite and thorite from Cerro Boggiani. Atoms per formula unit calculated on the basis of 4 oxygens.

\begin{tabular}{|c|c|c|c|c|c|c|}
\hline Sample & RP28 & RP31 & RP36 & RP38 & RP28 & RP36 \\
\hline & \multicolumn{2}{|c|}{ Uraninite } & \multicolumn{2}{|c|}{ Thorianite } & \multicolumn{2}{|c|}{ Thorite } \\
\hline $\mathrm{SiO}_{2}$ & nd & 0.15 & 0.92 & 0.90 & 21.15 & 22.40 \\
\hline $\mathrm{TiO}_{2}$ & nd & 0.53 & 0.41 & 0.70 & 2.48 & 7.03 \\
\hline $\mathrm{ZrO}_{2}$ & nd & 0.71 & 0.20 & 0.01 & 3.12 & 1.69 \\
\hline $\mathrm{Nb}_{2} \mathrm{O}_{5}$ & nd & - & 0.09 & 0.02 & 0.80 & 2.19 \\
\hline $\mathrm{Ta}_{2} \mathrm{O}_{5}$ & nd & - & $<0.19$ & 0.01 & 0.02 & 0.02 \\
\hline $\mathrm{WO}_{3}$ & nd & - & $<0.22$ & nd & 0.00 & 0.27 \\
\hline $\mathrm{Al}_{2} \mathrm{O}_{3}$ & nd & 0.06 & 0.41 & 0.06 & 0.76 & 3.69 \\
\hline $\mathrm{Y}_{2} \mathrm{O}_{3}$ & nd & 0.09 & $<0.06$ & 0.05 & 0.33 & 7.19 \\
\hline $\mathrm{La}_{2} \mathrm{O}_{3}$ & nd & 0.03 & 0.60 & 0.21 & 1.84 & 0.20 \\
\hline $\mathrm{Ce}_{2} \mathrm{O}_{3}$ & 0.28 & 0.01 & 2.60 & 0.45 & 2.16 & 0.53 \\
\hline $\mathrm{Pr}_{2} \mathrm{O}_{3}$ & nd & 0.01 & $<0.19$ & 0.06 & 0.17 & 0.12 \\
\hline $\mathrm{Nd}_{2} \mathrm{O}_{3}$ & 0.12 & 0.03 & 0.64 & 0.18 & 0.40 & 0.51 \\
\hline $\mathrm{Sm}_{2} \mathrm{O}_{3}$ & 0.18 & 0.08 & $<0.10$ & 0.03 & 0.05 & 0.33 \\
\hline $\mathrm{Gd}_{2} \mathrm{O}_{3}$ & 0.26 & 0.05 & $<0.20$ & 0.02 & 0.06 & 0.98 \\
\hline $\mathrm{Er}_{2} \mathrm{O}_{3}$ & 0.10 & 0.01 & $<0.26$ & 0.01 & 0.00 & 0.80 \\
\hline $\mathrm{Yb}_{2} \mathrm{O}_{3}$ & 0.14 & 0.01 & $<0.13$ & 0.01 & 0.08 & 0.22 \\
\hline $\mathrm{ThO}_{2}$ & 9.77 & 0.17 & 86.52 & 64.80 & 55.02 & 42.70 \\
\hline $\mathrm{UO}_{2}$ & 82.71 & 89.08 & 3.94 & 25.00 & 2.26 & 1.61 \\
\hline $\mathrm{Fe}_{2} \mathrm{O}_{3}$ & $<0.05$ & 0.33 & 0.32 & 1.53 & 0.31 & 3.01 \\
\hline $\mathrm{MnO}$ & $<0.01$ & 0.01 & $<0.07$ & 0.05 & 0.06 & 0.70 \\
\hline $\mathrm{MgO}$ & $<0.02$ & 0.01 & $<0.03$ & $<0.01$ & 0.00 & 0.15 \\
\hline $\mathrm{SrO}$ & $<0.02$ & - & $<0.04$ & nd & 0.12 & 0.06 \\
\hline $\mathrm{CaO}$ & 0.08 & 1.48 & 0.34 & 0.21 & 2.47 & 2.57 \\
\hline $\mathrm{PbO}$ & 3.95 & 1.60 & 1.01 & 3.81 & 0.11 & 0.04 \\
\hline $\mathrm{Na}_{2} \mathrm{O}$ & $<0.03$ & - & 0.12 & 0.10 & 0.08 & 0.60 \\
\hline $\mathrm{K}_{2} \mathrm{O}$ & $<0,01$ & - & $<0.03$ & 0.10 & 0.10 & 0.12 \\
\hline $\mathrm{BaO}$ & $<0.02$ & - & $<0.12$ & nd & 0.06 & 0.11 \\
\hline $\mathrm{F}$ & $<0.11$ & - & 0.17 & nd & 0.41 & 0.32 \\
\hline Sum & 98.67 & 94.45 & 99.30 & 98.32 & 94.42 & 100.27 \\
\hline \multicolumn{7}{|l|}{ Atoms } \\
\hline $\mathrm{Si}$ & - & 0.014 & 0.077 & 0.074 & 1.015 & 0.910 \\
\hline $\mathrm{Ti}$ & - & 0.034 & 0.025 & 0.042 & 0.088 & 0.176 \\
\hline $\mathrm{Zr}$ & - & 0.030 & 0.008 & - & 0.073 & 0.032 \\
\hline $\mathrm{Nb}$ & - & - & 0.004 & - & 0.017 & 0.038 \\
\hline $\mathrm{Ta}$ & - & - & & - & 0.001 & 0.000 \\
\hline W & - & - & & - & 0.000 & 0.003 \\
\hline $\mathrm{Al}$ & - & 0.003 & 0.040 & 0.06 & 0.043 & 0.171 \\
\hline $\mathrm{REE}+\mathrm{Y}$ & 0.090 & 0.009 & 0.135 & 0.055 & 0.091 & 0.212 \\
\hline $\mathrm{Th}$ & 0.201 & 0.004 & 1.633 & 1.215 & 0.601 & 0.398 \\
\hline $\mathrm{U}$ & 1.683 & 1.728 & 0.073 & 0.441 & 0.024 & 0.015 \\
\hline $\mathrm{Fe}$ & - & 0.022 & 0.020 & 0.104 & 0.011 & 0.085 \\
\hline $\mathrm{Mn}$ & - & - & 0.005 & -0.003 & 0.002 & 0.025 \\
\hline $\mathrm{Mg}$ & - & - & - & - & - & 0.009 \\
\hline $\mathrm{Sr}$ & - & - & 0.001 & - & 0.003 & 0.001 \\
\hline $\mathrm{Ca}$ & - & 0.134 & 0.030 & 0.018 & 0.127 & 0.110 \\
\hline $\mathrm{Pb}$ & 0.097 & 0.122 & 0.022 & 0.084 & 0.001 & 0.000 \\
\hline $\mathrm{Na}$ & - & - & 0.019 & 0.014 & 0.007 & 0.044 \\
\hline $\mathrm{K}$ & - & - & & 0.010 & 0.006 & 0.002 \\
\hline $\mathrm{Ba}$ & - & - & & - & 0.001 & 0.002 \\
\hline Sum & 2.071 & 2.100 & 2.092 & 2.066 & 2.111 & 2.233 \\
\hline
\end{tabular}

and rare earth elements (REE), mostly Ce, may substitute for Th in amounts up to $8 \mathrm{wt} \%$ (Fig. 6B). As a matter of fact, the $\mathrm{Y}_{2} \mathrm{O}_{3}+\mathrm{REE}$ content is up to about $5 \mathrm{wt} \%$ in thorianite and up to about $11 \mathrm{wt} \%$ in thorite of Cerro Boggiani. It should be also noted that thorianite compositions reported in Table 3 are similar to those found in carbonatites worldwide (cf. Moine et al., 1998), suggesting the influence of deuteric-metasomatic fluids deriving from a carbonatitic magma.

\subsection{Nb-bearing minerals (pyrochlore)}

Pyrochlore is the main Nb-bearing mineral phase (oxide) present in the Cerro Boggiani rocks. This mineral is commonly associated with late-stage magmatic to deuteric processes and carbonate-fluorite veins, most probably of metasomatic origin (Torro et al., 2012 and references therein). Notably, in carbonatites, pyroclore is a common phase (Hogarth, 1989; Hogarth and Horne, 1989), represented by a group including cubic $\mathrm{Nb}-\mathrm{Ta}-\mathrm{Ti}$ oxides expressed by the structural formula $\mathrm{A}_{16-x} \mathrm{~B}_{16} \mathrm{O}_{48}(\mathrm{O}, \mathrm{OH}, \mathrm{F})_{8-y}{ }^{*} \mathrm{zH}_{2} \mathrm{O}$, where $x$ and $y$ are vacant sites in the unit cell (cf. Zurevinski and Mitchell, 2004 and references therein). Pyrochlore structures may accommodate a wide variety of cations, with A-site potentially occupied by $\mathrm{As}, \mathrm{Ba}, \mathrm{Bi}, \mathrm{Ca}, \mathrm{Cs}, \mathrm{K}, \mathrm{Mg}$, $\mathrm{Mn}, \mathrm{Na}, \mathrm{Pb}, \mathrm{Y}, \mathrm{REE}, \mathrm{Sb}, \mathrm{Sr}$, Th and $\mathrm{U}$, and the B-site containing $\mathrm{Nb}$, Ta, Ti, V, Al, Si, Fe and Zr.

Notably, the A-sites from the Cerro Boggiani pyrochlores are mainly characterized by $\mathrm{Ca}(0.51-1.13$ a.f.u.), $\mathrm{Na}(0.19-0.96$ a.f.u.) and REE (Ce from 0.14 to 0.23 a.f.u.) (Table 4, Fig. 7A). The minerals occur in contact with other phases as shown in S3 and fall into the pyrochlore field of the $\mathrm{Ti}-\mathrm{Nb}-\mathrm{Ta}$ classification diagram (Fig. 7B). According to the $\mathrm{Ca}-\mathrm{Na}-\mathrm{A}_{\text {vacancies }}$ plot (Zurevinski and Mitchell, 2004 and references therein) in Fig. 7C, selected analyses of pyrochlore from phonolites (RP31 and RP41) and a nepheline syenite (RP38) may be considered to derive from both magmatic and hydrothermal crystallization. Indeed, pyrochlore crystals often show euhedral habits and should have mainly formed interstitially during late-stage magmatic to deuteric crystallization (e.g. Ridolfi et al., 2003, 2006).

This is supported by the analyses of substitutions (i) ${ }^{\mathrm{A}} \mathrm{Na}{ }^{\mathrm{Y}} \mathrm{F} \rightarrow{ }^{\mathrm{A}} \mathrm{\Upsilon}^{\mathrm{Y}} \mathrm{\Upsilon}$, (ii) ${ }^{\mathrm{A}} \mathrm{Ca}^{\mathrm{Y}} \mathrm{O} \rightarrow{ }^{\mathrm{A}} \mathrm{\Upsilon}^{\mathrm{Y}} \mathrm{\Upsilon}(\mathrm{Y}=$ vacancies) and (iii) ${ }^{\mathrm{A}} \mathrm{Ca}{ }^{\mathrm{X}} \mathrm{O} \rightarrow{ }^{\mathrm{A}} \mathrm{Y}^{\mathrm{X}} \mathrm{Y}$ in the representative pyrochlores (Fig.7). In fact, Lumpkin and Ewing (1995) recognized three types of alterations of the pyrochlore subgroup in nepheline syenites and carbonatites: primary alteration (i.e. hydrothermal), represented by the substitutions ${ }^{\mathrm{A}} \mathrm{Na}^{\mathrm{Y}} \mathrm{F} \rightarrow{ }^{\mathrm{A}} \mathrm{\Upsilon}^{\mathrm{Y}} \mathrm{Y}$ and ${ }^{\mathrm{A}} \mathrm{Ca}^{\mathrm{Y}} \mathrm{O} \rightarrow{ }^{\mathrm{A}} \mathrm{\Upsilon}^{\mathrm{Y}} \mathrm{\Upsilon}(\mathrm{\Upsilon}=$ vacancies $)$ promoted by a fluid-phase at $\sim 300-550{ }^{\circ} \mathrm{C}$; secondary alteration $\left(<150{ }^{\circ} \mathrm{C}\right.$, i.e. near surface, supergene), characterized by the same replacement reactions plus ${ }^{\mathrm{A}} \mathrm{Ca}^{\mathrm{X}} \mathrm{O} \rightarrow{ }^{\mathrm{A}} \mathrm{\Upsilon}^{\mathrm{X}} \mathrm{Y}$, and extreme hydration $\left(10-15 \mathrm{wt} \% \mathrm{H}_{2} \mathrm{O}\right.$ or $2-3$ molecules pfu); and finally, transitional alteration $\left(200-350{ }^{\circ} \mathrm{C}\right)$, in between the above two types of substitutions. According to the considerations above, the alteration patterns of the Cerro Boggiani pyrochlores (Fig.7) suggest that they underwent mostly primary and hydrothermal (transitional) alterations by high temperature $\left(\geq 200{ }^{\circ} \mathrm{C}\right)$ F-rich fluids. In conclusion, pyrochlore from Cerro Boggiani agpaitic rocks are both of late-stage magmatic and deuteric origin (sensu Mitchell, 2015), containing more A-site cations than supergene (wheatering) pyrochlore, the latter being dominated by A-site vacancies and water.

\subsection{REE-bearing minerals}

REE-rich minerals are represented by a large number of crystalline phases (from S4 to S9): carbonates (burbankite-remondite), fluorcarbonates (bastnäsite-parisite-synchysite, cordylite), hydrate 

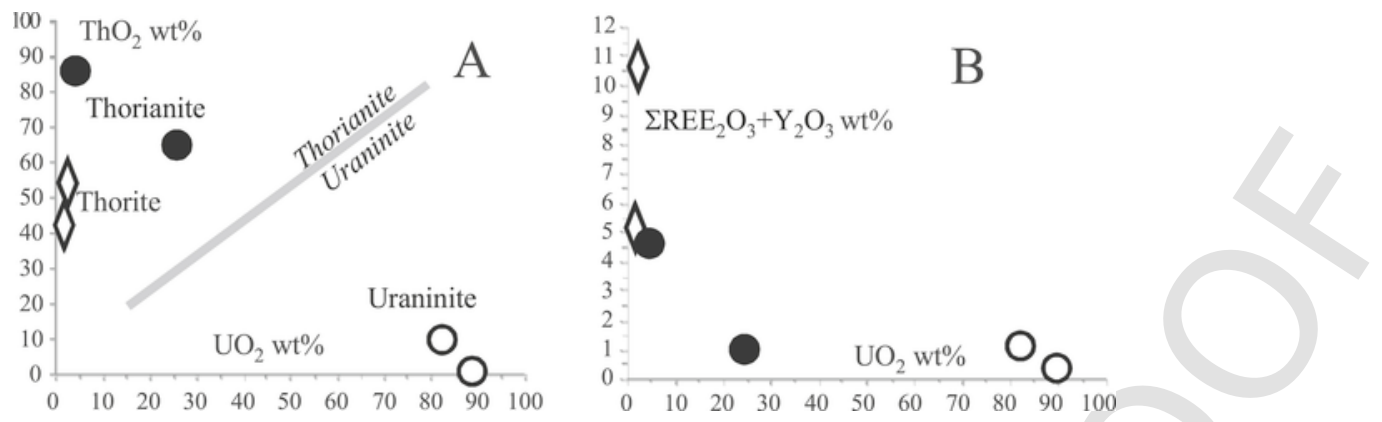

Fig. 6. $\mathrm{UO}_{2}$ vs. $\mathrm{ThO}_{2}$ (A) and $\mathrm{UO}_{2}$ vs. $\Sigma \mathrm{REE}+\mathrm{Y}_{2} \mathrm{O}_{3}$ (B) of thorianite, uraninite and thorite crystals from the Cerro Boggiani complex (after Förster, 1999 and references therein).

carbonates (ancylite, galgenbergite), phosphates (monazite) and silicate/phosphates (britholite). Carbonate, fluorcarbonate and hydrate carbonate phases from Cerro Boggiani have been the subjects of systematic investigations in the last decade (see e.g. Enrich et al., 2010).

\subsubsection{Carbonates: burbankite (remondite)}

The burbankite group is a rare strontium and cerium carbonate mineral (hexagonal) consisting of species with the general formula $\mathrm{A}_{3} \mathrm{~B}_{3}\left(\mathrm{CO}_{3}\right)_{5}$, where $\mathrm{A}=\mathrm{Na}>\mathrm{Ca}, \mathrm{REE}$ and $\mathrm{B}=\mathrm{Sr}, \mathrm{Ca}, \mathrm{Ba}, \mathrm{REE}, \mathrm{Na}$ (Belovtiskaya and Pekov, 2004 and references therein). Some crystals believed to be burbankite in the past, have now been identified as a new species called remondite (S4), which has a similar chemistry but monoclinic symmetry (Cesbron et al., 1988; Pekov et al., 2000). Representative chemical analyses are reported in Table 5 and SEM images are shown in S4 and S7.

Table 5 indicates that the dominant element in A-site is $\mathrm{Na}$ (2.17-3.0 a.f.u.), whereas the B-site contains various elements, i.e. $\mathrm{Ca}$ from 0.52 to 0.93 a.f.u., Sr from 0.22 to 1.26 a.f.u. and REE from 0.36 to 1.90 a.f.u.. Overall, the Cerro Boggiani burbankite (and remondite) plots in the field of the hydrothermalites (Fig. 8A) from nepheline syenite massifs at relatively low temperature, e.g. $250-100{ }^{\circ} \mathrm{C}$, according to the $\mathrm{CO}_{2}$ regime (cf. Belovtiskaya and Pekov, 2004; see also Fig. 5).

\subsubsection{Fluorcarbonates: bastnäsite-parisite-synchysite series}

The REE fluorcarbonates (Table 6) occur in significant amounts in the Cerro Boggiani minerals, for a total abundance of about $1 \mathrm{wt} \%$. In particular, the bastnäsite-parisite-synchysite series (S2, S5 and S7) are typically found as fine-scale, complex intergrowths of fibroradial to plumose aggregates in which bastnäsite and synchysite are dominant over parisite.

They show textures similar to the fluorcarbonate minerals described in Ruberti et al. (2008) and Ridolfi et al. (2006) for the Barra do Itapirapuã carbonatites and Kilombe alkali feldspar syenites. The three minerals show similar compositions [i.e.: bastnäsite $(\mathrm{Ca}$, $\mathrm{La})\left(\mathrm{CO}_{3}\right) \mathrm{F}$; parisite $\mathrm{Ca}(\mathrm{Ce}, \mathrm{La})_{2}\left(\mathrm{CO}_{3}\right) \quad{ }_{2} \mathrm{~F}_{2} ; \quad$ synchysite $\left.\mathrm{Ca}(\mathrm{Ce}, \mathrm{La})\left(\mathrm{CO}_{3}\right)_{2} \mathrm{~F}\right]$, but are easily distinguished in the $\Sigma(\mathrm{Ca}+\mathrm{Sr}) \mathrm{vs}$. $\Sigma$ REE diagram (Fig. 8B).

A comparison with other Brazilian occurrences indicates conditions, for the formation of the Cerro Boggiani fluorcarbonate mineral associations, at temperatures between 375 and $80^{\circ} \mathrm{C}$ (cf. Ruberti et al., 2008). It is worth noting that an origin of such fluorcarbonates from deuteric to metasomatic carbonatitic fluids is also suggested by the occurrence of thick intergrowths and corrosion phenomena among members of the series, as described by Ridolfi et al. (2006).

\subsubsection{Fluorcarbonates: cordylite}

Following Mills et al. (2012), cordylite, a Ba-fluorcarbonate, mainly occurs in metasomatic carbonate veins of the Biraya Fe-REE deposit (Irkutsk, Russia) closely associated with barite, biraite-(Ce), niobium-rich chevkinite-(Ce), fergusonite-( $\mathrm{Nd})$, ancylite, bastnäsite, hydroxylbastnäsite-(Ce), monazite-(Ce), talc, humite, thorite, pyrite, and pyrrhotite. In the phonolite dyke RP28 of Cerro Boggiani, a very fine-grained vein consists mainly of carbonates (not analysed) with single grains of cordyilite-(Ce- La), together with ancylite, bastnäsite, parisite, synchysite, låvenite, thorite and pyrochlore (S6).

The ideal formula of cordylite is $\left(\mathrm{Na}_{1-\mathrm{x}} \mathrm{Ca}_{\mathrm{x} / 2}\right) \mathrm{BaREE}_{2}\left(\mathrm{CO}_{3}\right)_{4} \mathrm{~F}$, with $0<\mathrm{x}<1$. It was redefined and simplified by Giester et al. (1998) to $\mathrm{NaBaCe}_{2}\left(\mathrm{CO}_{3}\right)_{4}$. In the Cerro Boggiani rocks, the cordylite composition (Table 6 ) roughly corresponds to the ideal formula proposed by Mills et al. (2012).

\subsubsection{Hydrate carbonates: ancylite and galgenbergite}

Microprobe analyses of ancylite and galgenbergite are reported in Table 7 (see also S3, S6, and S8) and represented in the REE-Sr-Ca diagram of Fig. 9.

Ancylite [ideal formula $\mathrm{SrCe}\left(\mathrm{CO}_{3}\right)_{2}(\mathrm{OH}) \cdot\left(\mathrm{H}_{2} \mathrm{O}\right)$, according to Pekov et al., 1997] from Cerro Boggiani shows REEs between 1.12 and 1.33 a.f.u., with prevailing $\mathrm{Ce}(0.54-0.70)$ and $\mathrm{La}(0.42-0.44)$, and subordinate $\mathrm{Nd}(0.10-0.12)$. Sr (0.46-0.54 a.f.u.) prevails over Ca (0.24-0.34), defining the field of ancylite s.s. (see Pekov et al., 1997). The anionic group includes $\mathrm{OH}^{-}(4.3-4.6 \mathrm{wt} \%)$ and $\mathrm{CO}_{3}{ }^{2-}$ (22.5-23.5 wt \%) and shows fluorine contents of $0.81-0.86 \mathrm{wt} \%$, corresponding to 0.18 a.f.u. (cf. Zaitsev et al., 1998).

Galgenbergites, with a simplified formula $\mathrm{Ca}(\mathrm{Ce}, \mathrm{La})_{2}\left(\mathrm{CO}_{3}\right)_{4}{ }^{*} \mathrm{H}_{2} \mathrm{O}$ according to Walter et al. (2013), occasionally occur in the Cerro Boggiani rocks (samples RP27 and RP36, Table 7). Considering a structural formula on the basis of $8 \mathrm{CO}_{3}$, Cerro Boggiani galgenbergites have REE contents of 3.6-3.7 a.f.u., $\mathrm{Ca}>\mathrm{Sr}$ and $\mathrm{Ca}+\mathrm{Sr}$ between 1.57 and 1.97 a.f.u..

\subsubsection{Phosphates: monazite}

Monazite, $\left[(\mathrm{Ce}, \mathrm{La}, \mathrm{Nd}, \mathrm{Th}) \mathrm{PO}_{4}\right]$, represents one of the most common REE and Th-rich accessory minerals (cf. Toledo and Pereira, 2003; Williams et al., 2007; Harlov and Hetherington, 2010 and references therein). The tetrahedral site of Cerro Boggiani monazites (Table 8$)$ is dominated by $\mathrm{P}$ (3.4-3.7 a.f.u.) and includes Si (0.2-0.4 a.f.u.) and $\mathrm{Al}(0.1-0.2$ a.f.u.). By contrast, the polyhedrons (coordination 9, according to Niet et al., 1995, and to Clavier et al., 2011) are largely occupied by REE + Y (3.5-4.0 a.f.u.) with $\mathrm{Ce}>\mathrm{La}$ (1.9 vs. 1.1-1.8 a.f.u., respectively); notably, Th ranges from 0.02 to 0.22 a.f.u.. Overall, the $\mathrm{Th}+\mathrm{U}$ and $\mathrm{REE}+\mathrm{Y}+\mathrm{P}$ are in the ranges of $0.60-0.18$ and $6.90-7.75$ a.f.u., respectively.

\subsubsection{Phosphates/silicates: britholite}

Britholite (S9), a basic phosphate/silicate mineral of sodium, calcium and $\mathrm{Ce}\left[(\mathrm{Ca}, \mathrm{Na})_{3} \mathrm{Ce}_{2}\left(\mathrm{SiO}_{4}\right)_{2}\left(\mathrm{PO}_{4}\right) \mathrm{F}\right.$, according to Oberti et al. (2001) and Pekov et al. (2007)], is a very rare accessory phase in the 
Table 4

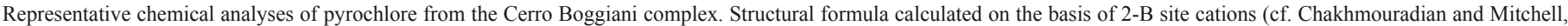
1998); $\mathrm{R}=$ rim

\begin{tabular}{|c|c|c|c|c|c|c|c|c|c|c|c|c|c|}
\hline $\begin{array}{l}\text { Rock- } \\
\text { type }\end{array}$ & $\begin{array}{l}\text { Phonolite } \\
\text { lava flow }\end{array}$ & $\begin{array}{l}\text { Phonolite } \\
\text { lava flow }\end{array}$ & $\begin{array}{l}\text { Nepheline } \\
\text { syenite }\end{array}$ & $\begin{array}{l}\text { Nepheline } \\
\text { syenite }\end{array}$ & $\begin{array}{l}\text { Nepheline } \\
\text { syenite }\end{array}$ & $\begin{array}{l}\text { Nepheline } \\
\text { syenite }\end{array}$ & $\begin{array}{l}\text { Nepheline } \\
\text { syenite }\end{array}$ & $\begin{array}{l}\text { Phonolite } \\
\text { lava flow }\end{array}$ & $\begin{array}{l}\text { Phonolite } \\
\text { lava flow }\end{array}$ & $\begin{array}{l}\text { Phonolite } \\
\text { lava flow }\end{array}$ & $\begin{array}{l}\text { Phonolite } \\
\text { lava flow }\end{array}$ & $\begin{array}{l}\text { Phonolite } \\
\text { lava flow }\end{array}$ & $\begin{array}{l}\text { Phonolite } \\
\text { lava flow }\end{array}$ \\
\hline Sample & RP31A & RP31BR & RP38B-1 & RP38B-2 & RP38B-3 & RP38B-4 R & RP38B-5 R & RP41-1 & RP41-2 & RP41-3 & RP41-4 & RP41-5 & RP41-6 R \\
\hline $\mathrm{SiO}_{2}$ & 1.41 & 0.00 & 4.18 & 3.27 & 0.73 & 3.86 & 3.39 & 4.87 & 3.34 & 9.38 & 1.41 & 2.16 & 0.00 \\
\hline $\mathrm{TiO}_{2}$ & 9.50 & 2.61 & 8.81 & 9.29 & 9.12 & 10.01 & 9.42 & 4.59 & 4.69 & 3.78 & 3.02 & 3.57 & 3.33 \\
\hline $\mathrm{ZrO}_{2}$ & 5.91 & 2.45 & 1.34 & 1.13 & 1.71 & 0.29 & 0.22 & 2.64 & 1.24 & 4.58 & 2.85 & 2.97 & 3.55 \\
\hline $\mathrm{Nb}_{2} \mathrm{O}_{5}$ & 35.64 & 45.53 & 52.90 & 54.63 & 56.39 & 47.84 & 48.44 & 51.71 & 53.28 & 46.80 & 55.09 & 57.01 & 50.54 \\
\hline $\mathrm{Ta}_{2} \mathrm{O}_{5}$ & 6.48 & 11.72 & 1.38 & 1.22 & 1.13 & 1.38 & 1.76 & 1.47 & 1.53 & 2.57 & 1.78 & 1.10 & 9.56 \\
\hline $\mathrm{WO}_{3}$ & - & - & $<0.19$ & 0.21 & 0.54 & $<0.19$ & $<0.19$ & 1.15 & 2.04 & $<0.19$ & 0.81 & 0.72 & - \\
\hline $\mathrm{Al}_{2} \mathrm{O}_{3}$ & 0.01 & 0.06 & 0.07 & 0.06 & 0.03 & 0.44 & 0.57 & 1.07 & 1.98 & 0.14 & 4.67 & 0.09 & 0.03 \\
\hline $\mathrm{Y}_{2} \mathrm{O}_{3}$ & - & - & 0.09 & $<0.05$ & $<0.05$ & $<0.05$ & $<0.05$ & $<0.05$ & $<0.05$ & $<0.05$ & $<0.05$ & $<0.05$ & 0.03 \\
\hline $\mathrm{La}_{2} \mathrm{O}_{3}$ & 1.35 & 0.08 & 0.27 & 0.41 & 1.65 & 1.42 & 1.60 & 1.81 & 2.01 & 0.98 & 2.46 & 2.23 & 0.13 \\
\hline $\mathrm{Ce}_{2} \mathrm{O}_{3}$ & 9.77 & 0.41 & 0.67 & 0.70 & 3.50 & 2.02 & 2.10 & 4.10 & 4.62 & 2.02 & 5.52 & 4.62 & 0.79 \\
\hline $\mathrm{Pr}_{2} \mathrm{O}_{3}$ & 0.60 & 0.02 & 0.21 & 0.19 & 0.40 & 0.18 & 0.26 & 0.29 & 0.38 & $<0.16$ & 0.38 & 0.31 & 0.03 \\
\hline $\mathrm{Nd}_{2} \mathrm{O}_{3}$ & 1.94 & 0.03 & 0.29 & 0.26 & 0.72 & 0.38 & 0.35 & 0.85 & 1.02 & 0.37 & 1.02 & 0.86 & 0.14 \\
\hline $\mathrm{Sm}_{2} \mathrm{O}_{3}$ & 0.21 & - & $<0.08$ & $<0.08$ & $<0.08$ & $<0.08$ & 0.09 & 0.13 & 0.19 & $<0.08$ & 0.14 & 0.13 & - \\
\hline $\mathrm{ThO}_{2}$ & 1.99 & 1.88 & 0.51 & 0.33 & 0.24 & 1.32 & 0.94 & 0.39 & 0.64 & 0.08 & 0.37 & 0.34 & 2.29 \\
\hline $\mathrm{UO}_{2}$ & 6.37 & 14.32 & 0.11 & $<0.06$ & 0.09 & 2.04 & 2.09 & 0.08 & $<0.06$ & 0.07 & $<0.06$ & $<0.06$ & 8.84 \\
\hline $\mathrm{FeO}$ & 1.71 & 1.25 & 0.50 & 0.26 & 0.15 & 1.45 & 1.62 & 0.13 & 0.75 & 0.14 & 0.15 & 0.14 & 1.07 \\
\hline $\mathrm{MnO}$ & - & 0.03 & 0.44 & 0.29 & 0.27 & 0.43 & 0.41 & 0.83 & 0.76 & 0.38 & 0.07 & 0.17 & 0,03 \\
\hline $\mathrm{MgO}$ & - & 0.07 & $<0.02$ & $<0.02$ & $<0.02$ & 0.06 & 0.04 & $<0.02$ & $<0.02$ & $<0.02$ & $<0.02$ & $<0.02$ & 0.09 \\
\hline $\mathrm{SrO}$ & - & 0.55 & 0.43 & 0.66 & 0.46 & 0.71 & 0.90 & 0.27 & 0.17 & 0.30 & 0.31 & 0.33 & 0.62 \\
\hline $\mathrm{CaO}$ & 16.26 & 8.73 & 14.35 & 15.71 & 13.70 & 10.64 & 10.78 & 9.69 & 8.34 & 10.57 & 9.13 & 10.39 & 8.08 \\
\hline $\mathrm{PbO}$ & - & 0.65 & $<0.10$ & $<0.10$ & $<0.10$ & 0.18 & 0.15 & $<0.10$ & $<0.10$ & $<0.10$ & $<0.10$ & $<0.10$ & 0.42 \\
\hline $\mathrm{Na}_{2} \mathrm{O}$ & 1.53 & 0.15 & 6.53 & 6.54 & 5.88 & 1.97 & 1.89 & 6.21 & 6.95 & 7.69 & 7.63 & 8.08 & 0.48 \\
\hline $\mathrm{K}_{2} \mathrm{O}$ & - & & 0.17 & 0.14 & 0.08 & 0.20 & 0.23 & 0.68 & 0.65 & 0.59 & 0.04 & 0.07 & \\
\hline $\mathrm{BaO}$ & - & 0.61 & 0.11 & 0.14 & $<0.10$ & 0.13 & $<0.10$ & $<0.10$ & $<0.10$ & $<0.10$ & $<0.10$ & $<0.10$ & 0.71 \\
\hline F & nd & 1.06 & 5.01 & 4.79 & 5.15 & 0.62 & 0.78 & 3.05 & 3.68 & 4.30 & 4.55 & 4.97 & 1.52 \\
\hline$-\mathrm{O}$ & - & 0.40 & 2.11 & 2.02 & 2.17 & 0.26 & 0.33 & 1.28 & 1.55 & 1.81 & 1.92 & 2.09 & 0.62 \\
\hline $\begin{array}{l}\text { Sum } \\
\text { B-site }\end{array}$ & 100.68 & 92.61 & 96.46 & 98.51 & 99.88 & 87.54 & 87.92 & 94.98 & 96.87 & 93.21 & 99.60 & 98.21 & 91.68 \\
\hline $\mathrm{Nb}$ & 1.048 & 1.462 & 1.334 & 1.373 & 1.482 & 1.268 & 1.302 & 1.338 & 1.383 & 1.159 & 1.377 & 1.578 & 1.491 \\
\hline $\mathrm{Ta}$ & 0.115 & 0.243 & 0.021 & 0.018 & 0.018 & 0.022 & 0.028 & 0.023 & 0.024 & 0.038 & 0.027 & 0.018 & 0.171 \\
\hline $\mathrm{Ti}$ & 0.465 & 0.133 & 0.370 & 0.389 & 0.399 & 0.442 & 0.421 & 0.198 & 0.202 & 0.156 & 0.125 & 0.164 & 0.164 \\
\hline $\mathrm{Si}$ & 0.092 & - & 0.233 & 0.182 & 0.042 & 0.227 & 0.201 & 0.279 & 0.192 & 0.514 & 0.078 & 0.132 & - \\
\hline $\mathrm{Zr}$ & 0.187 & 0.084 & 0.036 & 0.031 & 0.048 & 0.008 & 0.006 & 0.074 & 0.035 & 0.122 & 0.077 & 0.089 & 0.113 \\
\hline W & - & - & 0.001 & 0.003 & 0.008 & 0.002 & 0.001 & 0.017 & 0.030 & 0.002 & 0.012 & 0.011 & - \\
\hline $\mathrm{Al}$ & - & 0.003 & 0.005 & 0.004 & 0.002 & 0.031 & 0.040 & 0.072 & 0.134 & 0.009 & 0.304 & 0.006 & 0.002 \\
\hline $\mathrm{Fe}$ & 0.093 & 0.075 & - & - & - & - & - & - & - & - & - & - & 0.059 \\
\hline $\begin{array}{l}\text { Sum B } \\
\text { A-site }\end{array}$ & 2.000 & 2.000 & 2.000 & 2.000 & 2.000 & 2.000 & 2.000 & 2.000 & 2.000 & 2.000 & 2.000 & 2.000 & 2.000 \\
\hline $\mathrm{Ca}$ & 1.133 & 0.629 & 0.858 & 0.936 & 0.853 & 0.669 & 0.687 & 0.594 & 0.513 & 0.620 & 0.541 & 0.682 & 0.566 \\
\hline $\mathrm{La}$ & 0.032 & 0.002 & 0.006 & 0.008 & 0.035 & 0.031 & 0.035 & 0.038 & 0.042 & 0.020 & 0.050 & 0.050 & 0.003 \\
\hline $\mathrm{Ce}$ & 0.233 & 0.011 & 0.014 & 0.014 & 0.075 & 0.043 & 0.046 & 0.086 & 0.097 & 0.041 & 0.112 & 0.104 & 0.019 \\
\hline $\operatorname{Pr}$ & 0.014 & 0.000 & 0.004 & 0.004 & 0.008 & 0.004 & 0.006 & 0.006 & 0.008 & 0.001 & 0.008 & 0.007 & 0.001 \\
\hline $\mathrm{Nd}$ & 0.042 & 0.001 & 0.006 & 0.005 & 0.015 & 0.008 & 0.007 & 0.017 & 0.021 & 0.007 & 0.020 & 0.019 & 0.003 \\
\hline $\mathrm{Sm}$ & - & - & 0.001 & 0.001 & 0.001 & 0.001 & 0.002 & 0.003 & 0.004 & 0.000 & 0.003 & 0.003 & - \\
\hline $\mathrm{Th}$ & 0.029 & 0.031 & 0.007 & 0.004 & 0.003 & 0.018 & 0.013 & 0.005 & 0.008 & 0.001 & 0.005 & 0.005 & 0.034 \\
\hline $\mathrm{U}$ & 0.092 & 0.229 & 0.001 & 0.001 & 0.001 & 0.027 & 0.028 & 0.001 & 0.000 & 0.001 & 0.000 & 0.001 & 0.130 \\
\hline $\mathrm{Mn}$ & - & 0.002 & 0.021 & 0.014 & 0.013 & 0.021 & 0.021 & 0.040 & 0.037 & 0.018 & 0.003 & 0.009 & 0.002 \\
\hline $\mathrm{Mg}$ & - & 0.007 & 0.000 & 0.000 & 0.000 & 0.005 & 0.004 & 0.001 & 0.002 & 0.000 & 0.001 & 0.002 & 0.002 \\
\hline $\mathrm{Sr}$ & - & 0.024 & 0.014 & 0.021 & 0.015 & 0.024 & 0.031 & 0.009 & 0.005 & 0.010 & 0.010 & 0.012 & 0.023 \\
\hline $\mathrm{Pb}$ & - & 0.013 & 0.000 & 0.000 & 0.000 & 0.003 & 0.002 & 0.000 & 0.001 & 0.000 & 0.000 & 0.000 & 0.008 \\
\hline $\mathrm{Na}$ & 0.193 & 0.020 & 0.707 & 0.705 & 0.663 & 0.224 & 0.218 & 0.689 & 0.774 & 0.817 & 0.818 & 0.959 & 0.061 \\
\hline $\mathrm{K}$ & - & - & 0.012 & 0.010 & 0.006 & 0.015 & 0.017 & 0.050 & 0.048 & 0.041 & 0.003 & 0.006 & - \\
\hline $\mathrm{Ba}$ & - & 0.016 & 0.002 & 0.003 & 0.000 & 0.003 & 0.002 & 0.001 & 0.000 & 0.000 & 0.001 & 0.000 & 0.018 \\
\hline Sum A & 1.768 & 0.905 & 1.679 & 1.742 & 1.698 & 1.167 & 1.201 & 1.553 & 1.598 & 1.584 & 1.582 & 1.864 & 0.870 \\
\hline $\mathrm{F}$ & - & 0.233 & 0.884 & 0.843 & 0.946 & 0.115 & 0.146 & 0.552 & 0.669 & 0.744 & 0.796 & 0.963 & 0.313 \\
\hline
\end{tabular}

Cerro Boggiani rocks and shows $\mathrm{Ca}<\Sigma$ REE (i.e. 3.3 vs. 5.5 a.f.u.) with $\mathrm{Ce}=2.6$ and $\mathrm{Ce} / \mathrm{La}=1.02$ a.f.u.. The tetrahedral site contains 4.9 and 0.9 a.f.u. of Si and P, respectively (Table 8; cf. S9, associated to monazite). By contrast, the anionic site is characterized by $\mathrm{F}=2.64$ a.f.u. (cf. chemical composition of britholite from the Monte de Trigo Island nepheline syenites from Enrich and Ruberti, 2004). According to Andersen (2014, and references therein), monazite and britholite are stable at relatively high and low silica activities respec- tively, which is compatible with britholite occurrence in silica-undersaturated rocks.

\subsection{Zr-rich silicate minerals}

Zr-rich silicate phases of the Cerro Boggiani rocks are represented by rosenbuschite and låvenite (cuspidine-wöhlerite group), and eudialyte with subordinate catapleiite (Carbonin et al., 2005; 


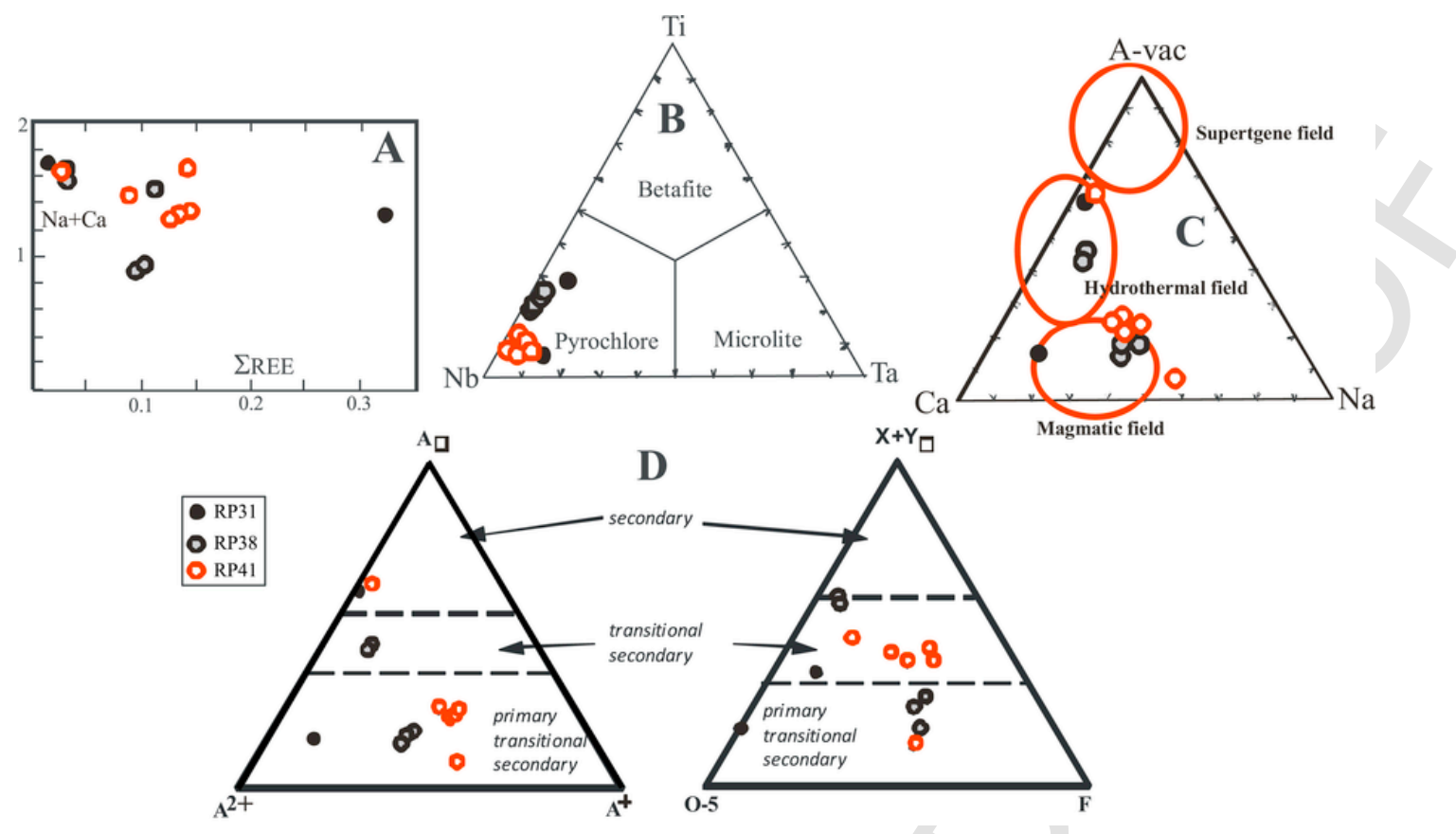

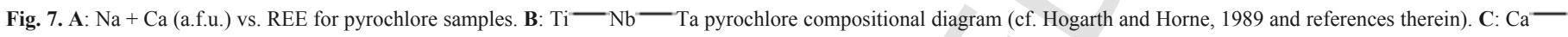

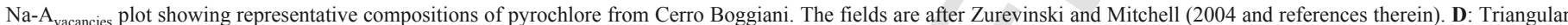

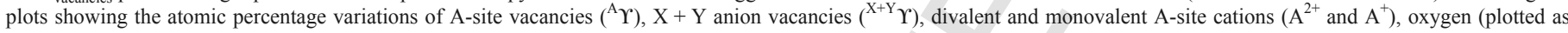

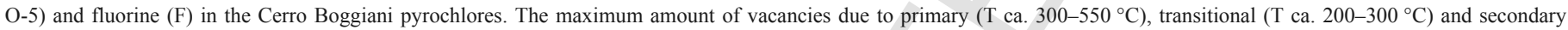
$\left(\mathrm{T}<150^{\circ} \mathrm{C}\right)$ alterations are also reported; after Lumpkin and Ewing (1995).

Comin-Chiaramonti et al., 2005; Enrich et al., 2011, 2012). Chemical analyses are reported in Table 9 (cf. also Fig. 2). As described by Carbonin et al. (2005), rosenbuschite and låvenite are disilicates characterized by tetrahedra pairs $\left(\mathrm{Si}_{2} \mathrm{O}_{7}\right)$ and by octahedral cations, varying from small-radius and high charge, i.e. $\mathrm{Ti}^{4+}, \mathrm{Zr}^{4+}$ and $\mathrm{Nb}^{5+}$ to $\mathrm{Mn}^{2+}$ and $\mathrm{Fe}^{2+}$, and larger-radius, low charge $\mathrm{Na}^{+}$and $\mathrm{Ca}^{2+}$ (Bellezza et al., 2003; Ridolfi et al., 2003). By contrast, eudialyte is a ring silicate, represented by a Na-rich zirconosilicate characterized by both three and nine-membered rings of $\mathrm{SiO}_{4}$ tetrahedra. Moreover, the mineral chemistry of these phases (Table 9; Fig.10) emphasizes high concentrations of $\mathrm{MnO}$ (i.e. rosenbuschite $2.8 \mathrm{wt} \%$, låvenite $6.0 \mathrm{wt} \%$ and eudialyte $4.8 \mathrm{wt} \%$; Table 9). In particular, Mn-rich eudialyte is considered as indicative of a postmagmatic/deuteric stage of crystallization (Aksenov et al., 2014).

\subsubsection{Rosenbuschite}

In the rosenbuschite group $\left(\mathrm{Na}_{6} \mathrm{Ca}_{6} \mathrm{Zr}_{3} \mathrm{Ti}\left(\mathrm{Si}_{2} \mathrm{O}_{7}\right)_{2} \mathrm{O}_{2} \mathrm{~F}_{2}\right)$, the polyhedra combine into layers ( $O$ layers) and into ribbons by edge sharing. Heterogeneous layers ( $H$ layers) composed of the octahedra from the ribbons and the sorosilicate groups alternate with the $O$ layer into a layered $\mathrm{HOH}$ structure (cf. Bellezza et al., 2003; Carbonin et al., 2005).

Although it shows $\mathrm{MnO}$ content between 2.7 and $2.9 \mathrm{wt} \%$ (Table 9), rosenbuschite from Cerro Boggiani (Fig. 2A-D) is consistent with the above crystal chemistry. This $\mathrm{MnO}$ abundance is significantly higher than typical rosenbuschite (e.g. from the Langesundfjord nepheline syenites in Norway) but similar to that found in Zaangar'ya rocks in Russia (Deer et al., 1997), as already noticed by Carbonin et al. (2005).

\subsubsection{Låvenite}

The analyses of the Cerro Boggiani låvenite yield the following crystal chemical formula, calculated on the basis of $9(\mathrm{O}, \mathrm{F})$ :

$$
\begin{aligned}
& \left(\mathrm{Na}_{1.34} \mathrm{Ca}_{0.66}\right)_{2.00}\left(\mathrm{Mn}_{0.38} \mathrm{Fe}_{0.22} \mathrm{Mg}_{0.01} \mathrm{Ti}_{0.16} \mathrm{Ca}_{0.18}\right)_{0.95} \\
& \left(\mathrm{Zr}_{0.74} \mathrm{Ti}_{0.16} \mathrm{Nb}_{0.10}\right)_{1.00}\left(\mathrm{Si}_{1.97} \mathrm{O}_{7.00}\right) \mathrm{O}_{0.88} \mathrm{~F}_{1.12}
\end{aligned}
$$

which is particularly close to the comprehensive chemical formula suggested by Mellini (1981), i.e. $\mathrm{W}_{2} \mathrm{XY}\left(\mathrm{Si}_{2} \mathrm{O}_{7}\right) \mathrm{O}(\mathrm{O}, \mathrm{OH}, \mathrm{F})$, where $\mathrm{W}=\mathrm{Na}, \mathrm{Ca} ; \mathrm{X}=\mathrm{Mn}, \mathrm{Fe}, \mathrm{Mg}, \mathrm{Ti}$ and some $\mathrm{Ca} ; \mathrm{Y}=\mathrm{Zr}, \mathrm{Ti}, \mathrm{Nb}, \mathrm{Ta}$ (cf. also Carbonin et al., 2005). As a matter of fact, the point analyses are in the låvenite field (Fig. 10A, B).

Similarly to the rosenbuschite, the high Mn concentration of the låvenite is noteworthy (up to $6 \mathrm{wt} \%$ ) and comparable to that of the same phase in the Junguni nepheline syenites from Malawi (Woolley and Platt, 1988), as previously observed by Carbonin et al. (2005).

\subsubsection{Eudialyte and Ca-catapleiite}

The Na-rich zirconosilicate eudialyte from the Cerro Boggiani (Fig. 2) has the following formula (see Johnsen and Grice, 1999 for calculation):

$$
\left(\mathrm{Na}_{10.85} \mathrm{Ca}_{1.70} \mathrm{~K}_{0.19} \mathrm{Sr}_{0.10} \mathrm{La}_{0.13} \mathrm{Ce}_{0.08}\right)_{13.05}\left(\mathrm{Ca}_{4.90} \mathrm{Mn}_{1.10}\right)_{6.00}
$$

$\left(\mathrm{Fe}_{2.02} \mathrm{Mn}_{0.96} \mathrm{Mg}_{0.02}\right)_{3.00} \mathrm{Zr}_{3.00}$

$$
\left(\mathrm{Nb}_{0.39} \mathrm{Ti}_{0.20} \mathrm{Zr}_{0.09} \mathrm{Si}_{0.33}\right)_{1.01} \mathrm{Si}_{24.96} \mathrm{Al}_{0.04} \mathrm{O}_{74.23} \mathrm{Cl}_{1.13}
$$

It indicates a cation deficiency in the Na sites. Notably, the calculated eudialyte analyses allow the mineral to be placed between eudialyte s.s. and a REE rich type (cf. Sjöqvist et al., 2013). The eudi- 
Table 5

Representative chemical analyses of burbankite (RP28, RP31 and RP38) and remondite (RP33 and RP41) from Cerro Boggiani. Atoms per formula unit based on 6 cations.

\begin{tabular}{|c|c|c|c|c|c|}
\hline Sample & RP28 & RP31 & RP33 & RP38 & RP41 \\
\hline $\mathrm{CaO}$ & 8.63 & 13.46 & 7.83 & 7.62 & 4.20 \\
\hline $\mathrm{SrO}$ & 16.70 & 19.42 & 3.46 & 9.37 & 3.68 \\
\hline $\mathrm{BaO}$ & 1.58 & 13.56 & 0.09 & 4.40 & 1.23 \\
\hline $\mathrm{La}_{2} \mathrm{O}_{3}$ & 15.24 & 2.34 & 15.85 & 13.42 & 18.04 \\
\hline $\mathrm{Ce}_{2} \mathrm{O}_{3}$ & 14.20 & 4.65 & 15.83 & 15.22 & 21.01 \\
\hline $\mathrm{Pr}_{2} \mathrm{O}_{3}$ & 0.78 & 0.37 & 1.21 & 1.22 & 1.97 \\
\hline $\mathrm{Nd}_{2} \mathrm{O}_{3}$ & 2.17 & 1.40 & 2.80 & 2.91 & 4.04 \\
\hline $\mathrm{Sm}_{2} \mathrm{O}_{3}$ & 0.15 & 0.10 & 0.43 & 0.29 & 0.45 \\
\hline $\mathrm{Gd}_{2} \mathrm{O}_{3}$ & 0.04 & 0.08 & 0.12 & 0.09 & 0.13 \\
\hline $\mathrm{Er}_{2} \mathrm{O}_{3}$ & 0.02 & - & $0.03-$ & 0.03 & 0.05 \\
\hline $\mathrm{Yb}_{2} \mathrm{O}_{3}$ & 0.01 & - & - & - & - \\
\hline $\mathrm{Y}_{2} \mathrm{O}_{3}$ & 0.02 & 0.10 & $0.12-$ & 0.04 & 0.12 \\
\hline $\mathrm{Na}_{2} \mathrm{O}$ & 12.74 & 9.69 & 16.32 & 12.99 & 14.76 \\
\hline $\mathrm{CO}_{2}$ & 27.55 & 33.32 & 34.11 & 32.22 & 29.90 \\
\hline Sum & 99.83 & 98.16 & 99.31 & 99.82 & 99.50 \\
\hline \multicolumn{6}{|l|}{ Atoms } \\
\hline $\mathrm{Na}$ & 2.643 & 2.166 & 3.000 & 2.847 & 3.000 \\
\hline $\mathrm{Ca}$ & 0.357 & 0.834 & - & 0.143 & - \\
\hline Sum A & 3.000 & 3.000 & 3.000 & 3.000 & 3.000 \\
\hline $\mathrm{Na}$ & - & - & 0.394 & - & 0.289 \\
\hline $\mathrm{Ca}$ & 0.628 & 0.777 & 0.925 & 0.751 & 0.516 \\
\hline $\mathrm{Sr}$ & 1.033 & 1.255 & 0.216 & 0.695 & 0.245 \\
\hline $\mathrm{Ba}$ & 0.060 & 0.603 & - & 0.188 & 0.044 \\
\hline $\mathrm{La}$ & 0.599 & 0.095 & 0.625 & 0.557 & 0.765 \\
\hline $\mathrm{Ce}$ & 0.554 & 0.191 & 0.627 & 0.627 & 0.882 \\
\hline $\operatorname{Pr}$ & 0.030 & 0.015 & 0.05 & 0.042 & 0.062 \\
\hline $\mathrm{Nd}$ & 0.082 & 0.055 & 0.105 & 0.118 & 0.166 \\
\hline $\mathrm{Sm}$ & 0.011 & 0.005 & 0.01 & 0.011 & 0.017 \\
\hline $\mathrm{Gd}$ & 0.001 & 0.003 & - & 0.004 & 0.005 \\
\hline Er & 0.001 & - & - & 0.001 & 0.002 \\
\hline Y & - & - & 0.010 & 0.005 & 0.007 \\
\hline Sum B & 2.999 & 3.000 & 2.952 & 3.000 & 3.000 \\
\hline
\end{tabular}

alyte compositions of Cerro Boggiani closely match those of the silica-undersaturated syenite nodules of Agua de Pau (Azores, Ridolfi et al., 2003).

Ca-catapleiite, typically formed as the result of metasomatic alteration of eudialyte (Karup-Møller et al., 2010 and references therein; Fig. 2) shows a more simplified composition, approximately $\mathrm{CaZrSi}_{3} \mathrm{O}_{9} 2 \mathrm{H}_{2} \mathrm{O}$ (cf. Table 8 and Merlino et al., 2004).

\section{Discussion and conclusions}

Electron microprobe analyses of accessory minerals in the nepheline syenite and phonolite rock-types from the Cerro Boggiani agpaitic complex (Alto Paraguay) confirm the presence of several phases enriched in $\mathrm{U}-\mathrm{Th}$ (uraninite-thorianite and thorite), $\mathrm{Nb}$ (py- rochlore), REEs (burbankite, bastnäsite-parisite-synchysite, cordylite, ancylite and galgenbergite, monazite and britholite) and $\mathrm{Zr}$ (rosenbuschite, låvenite and eudialyte). It is worth noting that these minerals usually crystallize at late magmatic and deuteric conditions (cf. Ruberti et al., 2008; Enrich et al., 2010 and references therein). In addition, the high content of volatiles (e.g. $\mathrm{CO}_{2}, \mathrm{~F}, \mathrm{Cl}$ and $\mathrm{H}_{2} \mathrm{O}$ ) and incompatible elements in the Cerro Boggiani complex is typical of agpaitic and carbonatitic magmas (cf. Kogarko et al., 1974, 1977; Kogarko, 1987; Woolley and Platt, 1988; Sørensen, 1997; Ruberti et al., 2008), not only related to a deuteric stage of crystallization but also to metasomatic mineralizing fluids, mainly giving rise to crystallization of accessory fluorcarbonates and hydrate carbonates. Among the hydrothermal fluids which affected the Cerro Boggiani nepheline syenites and phonolites, a qualitatively distinction between those with $\mathrm{H}_{2} \mathrm{O}>\mathrm{CO}_{2}$ (deuteric stricto sensu) and $\mathrm{CO}_{2} \geq \mathrm{H}_{2} \mathrm{O}$ (metasomatic) can be considered. It is worth noting that the term deuteric refers to reactions between primary magmatic minerals and the water-rich solutions that separate from the same body of magma at a late stage in its cooling history. By contrast, metasomatic minerals relates to fluids percolating through the crystallizing body but coming from outside that magmatic system. In the present case study of Cerro Boggiani rocks the metasomatic fluids are inferred to be of carbonatitic origin.

The LREE to MREE spider diagram patterns (normalized to chondrites CI; Fig.11) of pyroclore and REE-bearing minerals can give additional petrologic information. It is worth noting that positive Ce-spikes are typically found in magmatic pyrochlores of carbonatites (Hogarth et al., 1988; Hornig-Kjarsgaard, 1998; Wagner et al., 2003) and pyrochlore $\mathrm{Ce}$ anomaly of Cerro Boggiani varies from slightly negative to positive $\left(\mathrm{Ce} / \mathrm{Ce}^{*}=0.6-2.4\right)$. A similar feature is observed for a few Cerro Boggiani bastnäsite crystals showing $\mathrm{Ce} / \mathrm{Ce}$ * values up to 5.1 (Fig.11). In these crystals, the positive Ce anomaly is mostly due to low REE contents (other than Ce) with respect to other bastnäsite-parisite crystals (Table 6).

The other REE-minerals show strongly fractionated chondrite-normalized LREE patterns and no significant $\mathrm{Ce}$ anomaly $(\mathrm{Ce} /$ $\mathrm{Ce}^{*}=0.8-1.6$; Fig. 11). The chondrite normalized $\mathrm{La} / \mathrm{Nd}$ ratios is between 6 and 18, suggesting that mineralization is due to $\mathrm{CO}_{2}$-rich metasomatic fluids. This inference is supported by studies of fluid inclusions in REE-minerals such as fluorite, monazite and bastnäsite-parisite (Smith et al., 2000). Smith et al. (2000) have shown that mineral REEs partitioning can be correlated with the composition and temperature of the mineralizing fluids. Due to the occurrence of REE complexes at low temperature and with $\mathrm{H}_{2} \mathrm{O}$-rich fluids, partitioning of rare earth elements typically increases with atomic number, leading to higher MREE solubility. Accordingly, the crystallization of REE-minerals with $\mathrm{La} / \mathrm{Nd}_{\mathrm{N}}$ ratios $<2$ takes places in dominant aqueous solutions at low temperatures (minimum estimates of $150-250{ }^{\circ} \mathrm{C}$ ), whereas REE phases with $\mathrm{La} / \mathrm{Nd}_{\mathrm{N}}>4$
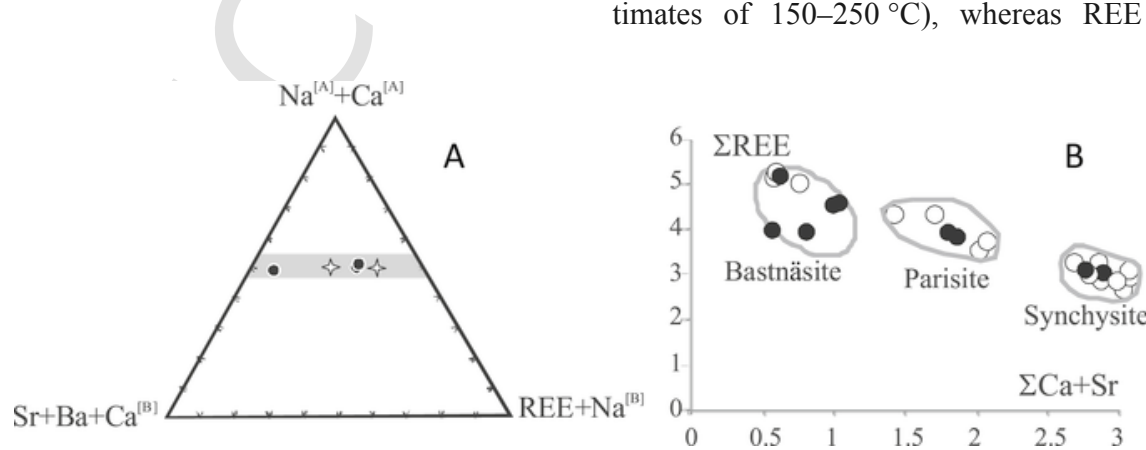

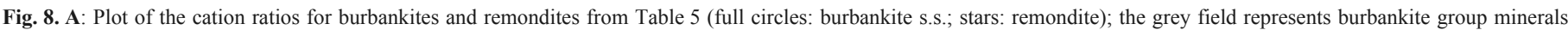

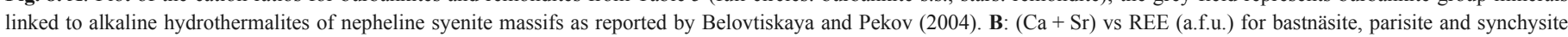
minerals; the fields are after Gieré (1996); full circles: this work; open circles: from Ruberti et al. (2008). 
Table 6

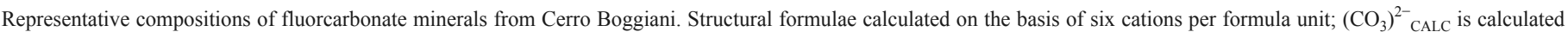
by charge balance.

\begin{tabular}{|c|c|c|c|c|c|c|c|c|c|c|}
\hline \multirow[t]{2}{*}{ Sample } & \multicolumn{5}{|c|}{ Bastnäsite } & \multicolumn{2}{|c|}{ Parisite } & \multicolumn{2}{|c|}{ Synchysite } & \multirow{2}{*}{$\begin{array}{l}\text { Cordylite } \\
\text { RP28 }\end{array}$} \\
\hline & RP28 & RP31A & RP31B & RP36 & RP38 & RP28 & RP31A & RP28 & RP31A & \\
\hline $\mathrm{SiO}_{2}$ & 3.07 & - & 0.74 & 0.33 & 0.30 & 0.06 & 0.08 & 0.05 & 0.04 & - \\
\hline $\mathrm{Al}_{2} \mathrm{O}_{3}$ & 0.79 & 0.01 & 0.04 & 0.76 & - & 0.44 & 0.99 & 0.04 & 0.03 & - \\
\hline $\mathrm{Fe}_{2} \mathrm{O}_{3}$ & 0.53 & - & 4.59 & 0.14 & 0.40 & - & $<0.05$ & - & - & 0.11 \\
\hline $\mathrm{Y}_{2} \mathrm{O}_{3}$ & 0.45 & 0.58 & 0.44 & - & 1.70 & 0.26 & 0.27 & 0.38 & 0.48 & 0.44 \\
\hline $\mathrm{La}_{2} \mathrm{O}_{3}$ & 15.31 & 23.92 & 18.66 & 28.84 & 25.01 & 23.80 & 22.74 & 18.56 & 17.98 & 14.65 \\
\hline $\mathrm{Ce}_{2} \mathrm{O}_{3}$ & 39.05 & 30.05 & 28.90 & 28.79 & 30.91 & 28.25 & 27.53 & 25.26 & 24.73 & 22.82 \\
\hline $\mathrm{Pr}_{2} \mathrm{O}_{3}$ & 1.11 & 1.97 & 1.87 & 1.30 & 1.68 & 1.67 & 1.71 & 1.71 & 1.69 & 1.11 \\
\hline $\mathrm{Nd}_{2} \mathrm{O}_{3}$ & 3.24 & 6.24 & 5.59 & 3.22 & 4.56 & 4.65 & 5.06 & 5.46 & 5.67 & 3.04 \\
\hline $\mathrm{Sm}_{2} \mathrm{O}_{3}$ & 0.48 & 0.78 & 0.70 & 0.36 & 0.66 & 0.37 & 0.47 & 0.57 & 0.56 & 0.23 \\
\hline $\mathrm{Eu}_{2} \mathrm{O}_{3}$ & - & 0.30 & - & - & 0.52 & 0.18 & 0.16 & 0.17 & 0.19 & - \\
\hline $\mathrm{Gd}_{2} \mathrm{O}_{3}$ & 0.06 & 0.70 & 0.24 & - & 1.70 & 0.29 & 0.37 & 0.44 & 0.46 & 0.07 \\
\hline $\mathrm{Dy}_{2} \mathrm{O}_{3}$ & 0.06 & 0.21 & - & - & 0.31 & 0.09 & 0.10 & 0.13 & 0.15 & 0.06 \\
\hline $\mathrm{ThO}_{2}$ & 1.90 & 2.60 & 4.65 & 0.58 & 0.24 & 3.04 & 3.87 & 2.48 & 3.87 & 2.69 \\
\hline $\mathrm{UO}_{2}$ & 0.17 & 0.02 & 0.11 & - & - & 0.05 & 0.05 & 0.05 & 0.06 & 0.06 \\
\hline $\mathrm{MnO}$ & - & - & 0.20 & - & - & - & - & - & - & 0.02 \\
\hline $\mathrm{SrO}$ & 0.61 & 2.03 & 0.84 & 0.07 & 0.47 & 1.61 & 1.66 & 1.88 & 1.12 & 1.83 \\
\hline $\mathrm{BaO}$ & - & - & - & - & - & - & - & - & - & 17.75 \\
\hline $\mathrm{CaO}$ & 3.91 & 1.51 & 2.21 & 4.75 & 4.81 & 8.54 & 8.80 & 15.52 & 16.29 & 1.83 \\
\hline $\mathrm{Na}_{2} \mathrm{O}$ & 0.75 & - & 0.62 & 0.28 & 0.10 & - & - & - & - & 3.00 \\
\hline $\mathrm{K}_{2} \mathrm{O}$ & 0.15 & - & 0.07 & 0.03 & - & - & - & - & - & 0.06 \\
\hline F & 5.57 & 8.63 & 6.22 & 6.79 & 6.66 & 8.35 & 8.44 & 8.70 & 9.08 & 2.43 \\
\hline $\mathrm{Cl}$ & 0.05 & - & - & 0.03 & - & - & - & - & - & - \\
\hline$-\mathrm{O}=\mathrm{F}, \mathrm{Cl}$ & 2.36 & 3.64 & 2.62 & 2.87 & 2.81 & 3.60 & 3.55 & 3.66 & 3.83 & 1.02 \\
\hline Sum & 74.90 & 75.91 & 74.80 & 73.87 & 75.82 & 78.00 & 78.43 & 77.74 & 77.75 & 78.65 \\
\hline Atoms & & & & & & & & & & \\
\hline $\mathrm{Ca}$ & 0.737 & 0.356 & 0.461 & 1.007 & 1.010 & 1.637 & 1.668 & 2.682 & 2.795 & 0.505 \\
\hline $\mathrm{Sr}$ & 0.064 & 0.260 & 0.094 & 0.008 & 0.054 & 0.170 & 0.175 & 0.088 & 0.102 & 0.109 \\
\hline $\mathrm{Ba}$ & & & & & & & - & - & - & 1.789 \\
\hline $\mathrm{Na}$ & 0.265 & - & 0.233 & 0.106 & 0.038 & - & - & - & - & 0.497 \\
\hline $\mathrm{K}$ & 0.035 & - & 0.018 & 0.008 & 0.004 & - & - & - & - & 0.019 \\
\hline$\Sigma$ & 1.101 & 0.616 & 0.806 & 1.129 & 1.106 & 1.807 & 1.843 & 2.770 & 2.897 & 2.999 \\
\hline $\mathrm{Si}$ & 0.560 & - & 0.144 & 0.065 & 0.059 & 0.010 & 0.013 & 0.008 & 0.005 & - \\
\hline $\mathrm{Al}$ & 0.170 & - & 0.010 & 0.177 & 0.004 & 0.093 & 0.124 & 0.004 & 0.004 & - \\
\hline $\mathrm{Fe}$ & 0.073 & - & 0.672 & 0.020 & 0.059 & - & - & - & - & 0.021 \\
\hline $\mathrm{Y}$ & 0.043 & 0.068 & 0.045 & 0.005 & 0.177 & 0.024 & 0.029 & 0.032 & 0.040 & 0.060 \\
\hline $\mathrm{La}$ & 1.030 & 1.948 & 1.340 & 2.104 & 1.806 & 1.595 & 1.499 & 1.106 & 1.053 & 1.389 \\
\hline $\mathrm{Ce}$ & 2.608 & 2.429 & 2.060 & 2.085 & 2.216 & 1.877 & 1.813 & 1.495 & 1.438 & 2.151 \\
\hline $\operatorname{Pr}$ & 0.074 & 0.158 & 0.133 & 0.094 & 0.120 & 0.135 & 0.112 & 0.101 & 0.098 & 0.103 \\
\hline $\mathrm{Nd}$ & 0.211 & 0.492 & 0.388 & 0.227 & 0.319 & 0.301 & 0.325 & 0.316 & 0.303 & 0.278 \\
\hline $\mathrm{Sm}$ & 0.030 & 0.060 & 0.047 & 0.025 & 0.044 & 0.023 & 0.029 & 0.031 & 0.031 & 0.021 \\
\hline $\mathrm{Eu}$ & - & 0.023 & - & - & - & 0.008 & 0.010 & 0.010 & 0.011 & - \\
\hline $\mathrm{Gd}$ & 0.004 & 0.052 & 0.016 & 0.008 & 0.034 & 0.017 & 0.022 & 0.024 & 0.024 & 0.006 \\
\hline Dy & 0.003 & 0.015 & - & 0.002 & 0.019 & 0.004 & 0.006 & 0.004 & 0.006 & 0.005 \\
\hline $\mathrm{Th}$ & 0.078 & 0.130 & 0.206 & 0.026 & 0.011 & 0.125 & 0.159 & 0.090 & 0.118 & 0.160 \\
\hline $\mathrm{U}$ & 0.013 & 0.002 & 0.005 & - & 0.003 & 0.002 & 0.003 & 0.001 & 0.001 & 0.004 \\
\hline$\Sigma$ & 4.897 & 5.377 & 5.066 & 4.811 & 4.871 & 4.214 & 4.158 & 3.222 & 3.139 & 4.198 \\
\hline $\mathrm{F}$ & 3.213 & 6.027 & 3.832 & 4.250 & 4.125 & 4.924 & 4.810 & 4.439 & 4.545 & 1.972 \\
\hline $\mathrm{Cl}$ & 0.015 & - & - & 0.009 & - & - & - & - & - & - \\
\hline$\left(\mathrm{CO}_{3}\right)^{2-}$ CALC & 6.252 & 6.073 & 6.464 & 6.308 & 6.363 & 6.068 & 6.007 & 6.049 & 6.063 & 8.008 \\
\hline
\end{tabular}

should have originated from $\mathrm{CO}_{2}$-rich fluids (with $\mathrm{XCO}_{2}$ up to 0.84 ) (Smith et al., 2000; Ridolfi et al., 2006).

According to textural relationships and the overall mineral chemistry of the investigated accessory phases, coupled with compositional comparisons with the same mineral species in agpaitic-carbonatitic igneous complexes worldwide, a sequence of late accessory minerals of the Cerro Boggiani nepheline syenites and phonolites is emphasized. As shown in Fig. 12 the investigated rare accessory minerals of Cerro Boggiani can be distinguished in: 1) late-stage magmatic, 2) hydrothermal deuteric, and 3 ) hydrothermal metasomatic (carbonatitic fluids-related).

The deuteric stage of the agpaitic Cerro Boggiani nepheline syenites and phonolites was followed by the crystallization of some accessory minerals driven by carbonatitic fluids (Haas et al., 1995;
Zaitsev et al., 1998). It is therefore inferred that $\mathrm{CO}_{2^{-}}, \mathrm{F}-, \mathrm{H}_{2} \mathrm{O}-$, and LREE-rich carbonatitic fluids percolated through the subvolcanic system and interacted with the Cerro Boggiani peralkaline and agpaitic silicate melts during and shortly after their magmatic crystallization.

\section{Uncited reference}

Birkett et al., 1992, Mahato et al., 2013.

\section{Acknowledgements}

We would like to thank Brazilian agencies (FAPESP Proc. 2013/ 18073-4 and 2012/06082-6) for the financial support. Two anony- 
Table 7

Representative analyses of hydrate carbonates from Cerro Boggiani. Structural formulae for ancylite are calculated on the basis of two cations; calc.*, wt.\%, calculated according to Dal Negro et al. (1975). Structural formulae for galgenbergite are based on $\left(8 \mathrm{CO}_{3}\right)$, according to Walter et al. (2013).

\begin{tabular}{|c|c|c|c|c|}
\hline \multirow[t]{2}{*}{ Sample } & \multicolumn{2}{|l|}{ Ancylite } & \multicolumn{2}{|c|}{ Galgenbergite } \\
\hline & RP30 & RP38 & RP27 & RP36 \\
\hline $\mathrm{Al}_{2} \mathrm{O}_{3}$ & 0.27 & 0.17 & 0.48 & 1.20 \\
\hline $\mathrm{Y}_{2} \mathrm{O}_{3}$ & - & - & 0.05 & 0.01 \\
\hline $\mathrm{La}_{2} \mathrm{O}_{3}$ & 17.83 & 18.10 & 24.82 & 26.88 \\
\hline $\mathrm{Ce}_{2} \mathrm{O}_{3}$ & 23.47 & 29.05 & 22.53 & 23.86 \\
\hline $\mathrm{Pr}_{2} \mathrm{O}_{3}$ & 1.40 & 2.03 & 1.19 & 1.17 \\
\hline $\mathrm{Nd}_{2} \mathrm{O}_{3}$ & 4.18 & 4.96 & 3.05 & 2.88 \\
\hline $\mathrm{Sm}_{2} \mathrm{O}_{3}$ & 0.44 & 0.33 & 0.37 & 0.27 \\
\hline $\mathrm{ThO}_{2}$ & 0.16 & - & 0.10 & 0.45 \\
\hline $\mathrm{UO}_{2}$ & - & - & 0.06 & 0.02 \\
\hline $\mathrm{Fe}_{2} \mathrm{O}_{3}$ & 0.28 & - & 0.67 & 0.93 \\
\hline $\mathrm{MnO}$ & - & - & 0.07 & - \\
\hline $\mathrm{SrO}$ & 12.87 & 14.20 & 6.75 & 2.44 \\
\hline $\mathrm{CaO}$ & 5.05 & 3.95 & 6.10 & 6.28 \\
\hline $\mathrm{BaO}$ & 0.16 & 0.79 & - & - \\
\hline $\mathrm{Na}_{2} \mathrm{O}$ & - & - & 0.22 & 0.69 \\
\hline $\mathrm{K}_{2} \mathrm{O}$ & 0.09 & - & - & 0.05 \\
\hline $\mathrm{F}$ & 0.81 & 0.86 & 0.93 & 0.92 \\
\hline $\mathrm{Cl}$ & - & - & - & 0.01 \\
\hline$-\mathrm{O}=\mathrm{F}, \mathrm{Cl}$ & 0.34 & 0.36 & 0.39 & 0.39 \\
\hline $\mathrm{CO}_{2}$ calc $^{*}$ & 23.51 & 22.53 & 29.96 & 29.31 \\
\hline $\mathrm{OH}$ calc* & 4.64 & 4.33 & - & - \\
\hline $\mathrm{H}_{2} \mathrm{O}$ calc* & 3.94 & 3.82 & 2.29 & 2.23 \\
\hline Sum & 101.23 & 98.51 & 99.94 & 98.92 \\
\hline Atoms & & & & \\
\hline $\mathrm{Al}$ & 0.020 & 0.013 & 0.107 & 0.102 \\
\hline Y & - & - & 0.005 & 0.001 \\
\hline $\mathrm{La}$ & 0.421 & 0.440 & 1.728 & 1.685 \\
\hline $\mathrm{Ce}$ & 0.538 & 0.702 & 1.557 & 1.698 \\
\hline $\operatorname{Pr}$ & 0.033 & 0.049 & 0.082 & 0.082 \\
\hline $\mathrm{Nd}$ & 0.096 & 0.117 & 0.206 & 0.199 \\
\hline $\mathrm{Sm}$ & 0.010 & 0.007 & 0.024 & 0.018 \\
\hline $\mathrm{Gd}$ & 0.003 & 0.003 & 0.001 & 0.001 \\
\hline $\mathrm{Th}$ & 0.002 & 0.001 & 0.005 & 0.020 \\
\hline $\mathrm{U}$ & - & - & 0.002 & 0.001 \\
\hline $\mathrm{Fe}$ & 0.014 & - & 0.094 & 0.135 \\
\hline $\mathrm{Mn}$ & - & - & 0.011 & - \\
\hline Sum & 1.138 & 1.332 & 3.822 & 3.942 \\
\hline $\mathrm{Sr}$ & 0.465 & 0.536 & 0.740 & 0.273 \\
\hline $\mathrm{Ca}$ & 0.337 & 0.245 & 1.233 & 1.299 \\
\hline $\mathrm{Ba}$ & 0.004 & - & - & - \\
\hline Sum & 0.806 & 0.658 & 1.973 & 1.572 \\
\hline F & 0.172 & 0.184 & 0.558 & 0.562 \\
\hline
\end{tabular}

Fig. 9. REE-Sr-Ca variation diagram for ancylite (full circles) and galgenbergite (stars) from Cerro Boggiani samples (cf. Table 7). The grey field represents the composition of world-wide ancylites and Ca-ancylites after Pekov et al. (1997).
Table 8

Representative analyses of monazite (cations on the basis of 16 oxygens) and britholite (number of ions on the basis of $26(\mathrm{O}, \mathrm{F})$; according to Oberti et al. (2001).

\begin{tabular}{|c|c|c|c|}
\hline \multirow[t]{2}{*}{ Sample } & \multicolumn{2}{|c|}{ Monazite } & \multirow{2}{*}{$\begin{array}{l}\text { Britholite } \\
\text { RP36 }\end{array}$} \\
\hline & RP28 & RP36 & \\
\hline $\mathrm{SiO}_{2}$ & 2.30 & 0.99 & 18.57 \\
\hline $\mathrm{P}_{2} \mathrm{O}_{5}$ & 23.85 & 28.06 & 4.17 \\
\hline $\mathrm{Al}_{2} \mathrm{O}_{3}$ & 0.82 & 0.46 & 0.45 \\
\hline $\mathrm{Y}_{2} \mathrm{O}_{3}$ & 0.42 & - & 0.04 \\
\hline $\mathrm{La}_{2} \mathrm{O}_{3}$ & 17.11 & 30.99 & 25.95 \\
\hline $\mathrm{Ce}_{2} \mathrm{O}_{3}$ & 31.24 & 33.33 & 26.65 \\
\hline $\mathrm{Pr}_{2} \mathrm{O}_{3}$ & 2.16 & 1.38 & 1.23 \\
\hline $\mathrm{Nd}_{2} \mathrm{O}_{3}$ & 5.64 & 3.55 & 2.88 \\
\hline $\mathrm{Sm}_{2} \mathrm{O}_{3}$ & 0.56 & 0.41 & 0.27 \\
\hline $\mathrm{Gd}_{2} \mathrm{O}_{3}$ & 0.25 & 0.06 & - \\
\hline $\mathrm{ThO}_{2}$ & 5.75 & 0.61 & 3.23 \\
\hline $\mathrm{UO}_{2}$ & - & - & 0.08 \\
\hline $\mathrm{Fe}_{2} \mathrm{O}_{3}$ & - & - & 0.58 \\
\hline $\mathrm{MnO}$ & - & - & 0.28 \\
\hline $\mathrm{SrO}$ & 0.69 & 0.09 & 0.35 \\
\hline $\mathrm{CaO}$ & 2.02 & 0.34 & 11.84 \\
\hline $\mathrm{Na}_{2} \mathrm{O}$ & 0.47 & - & 0.41 \\
\hline $\mathrm{K}_{2} \mathrm{O}$ & 0.06 & - & 0.18 \\
\hline $\mathrm{BaO}$ & 0.26 & - & - \\
\hline $\mathrm{F}$ & 0.98 & 0.13 & 3.15 \\
\hline $\mathrm{Cl}$ & 0.11 & - & 0.01 \\
\hline$-\mathrm{O}^{-}$ & 0.44 & 0.05 & 1.33 \\
\hline Sum & 94.35 & 100.45 & 98.99 \\
\hline Atoms & & & \\
\hline $\mathrm{P}$ & 3.381 & 3.729 & 0.912 \\
\hline $\mathrm{Si}$ & 0.384 & 0.157 & 4.880 \\
\hline $\mathrm{Al}$ & 0.163 & 0.091 & 0.135 \\
\hline Sum & 3.928 & 3.977 & 5.927 \\
\hline $\mathrm{Y}$ & 0.037 & 0.003 & 0.006 \\
\hline $\mathrm{La}$ & 1.056 & 1.797 & 2.528 \\
\hline $\mathrm{Ce}$ & 1.915 & 1.917 & 2.576 \\
\hline $\operatorname{Pr}$ & 0.132 & 0.079 & 0.118 \\
\hline $\mathrm{Nd}$ & 0.337 & 0.199 & 0.272 \\
\hline $\mathrm{Sm}$ & 0.033 & 0.022 & 0.024 \\
\hline Gd & 0.014 & 0.007 & - \\
\hline Th & 0.219 & 0.022 & 0.188 \\
\hline $\mathrm{Fe}$ & - & - & 0.113 \\
\hline $\mathrm{Mn}$ & - & - & 0.059 \\
\hline $\mathrm{Sr}$ & 0.067 & 0.009 & 0.054 \\
\hline $\mathrm{Ca}$ & 0.362 & 0.059 & 3.332 \\
\hline $\mathrm{Na}$ & 0.154 & - & 0.170 \\
\hline $\mathrm{K}$ & 0.013 & - & 0.057 \\
\hline $\mathrm{Ba}$ & 0.017 & - & - \\
\hline Sum & 4.360 & 4.114 & 9.498 \\
\hline $\mathrm{F}$ & 0.516 & 0.131 & 2.637 \\
\hline $\mathrm{Cl}$ & 0.032 & - & - \\
\hline
\end{tabular}

mous reviewers are acknowledged for very useful suggestion and comments leading to the revised and final version of the manuscript which was strongly improved.

\section{Appendix A. Supplementary data}

Supplementary data related to this article can be found at http://dx. doi.org/10.1016/j.jsames.2016.08.003. 
Table 9

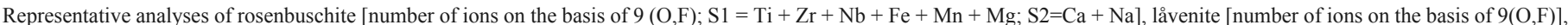

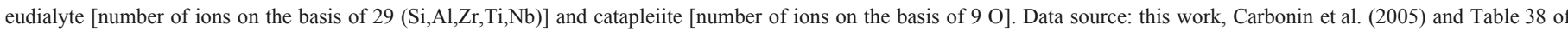
Comin-Chiaramonti et al. (2005).

\begin{tabular}{|c|c|c|c|c|c|c|c|c|c|}
\hline \multirow[t]{2}{*}{ Sample } & \multicolumn{2}{|c|}{ Rosenbuschite } & \multicolumn{2}{|c|}{ Låvenite } & \multirow[t]{2}{*}{ Sample } & \multicolumn{2}{|c|}{ Eudialyte } & \multicolumn{2}{|c|}{ Ca-catapleiite } \\
\hline & RP31 & RP33 & RP33 & RP40 & & RP33 & RP33B & RP33 & \\
\hline $\mathrm{SiO}_{2}$ & 31.22 & 31.37 & 32.58 & 30.95 & $\mathrm{SiO}_{2}$ & 49.98 & 49.38 & $\mathrm{SiO}_{2}$ & 44.69 \\
\hline $\mathrm{TiO}_{2}$ & 7.63 & 8.14 & 3.75 & 4.37 & $\mathrm{Al}_{2} \mathrm{O}_{3}$ & 0.10 & 0.12 & $\mathrm{ZrO}_{2}$ & 31.00 \\
\hline $\mathrm{ZrO}_{2}$ & 14.36 & 13.42 & 29.90 & 27.76 & $\mathrm{TiO}_{2}$ & 0.40 & 0.14 & $\mathrm{CaO}^{2}$ & 13.82 \\
\hline $\mathrm{Nb}_{2} \mathrm{O}_{5}$ & 1.25 & 1.64 & 1.40 & 2.10 & $\mathrm{ZrO}_{2}$ & 12.46 & 12.34 & $\mathrm{Na}_{2} \mathrm{O}$ & 0.32 \\
\hline $\mathrm{FeO}$ & 0.95 & 0.65 & 2.97 & 2.82 & $\mathrm{Nb}_{2} \mathrm{O}_{5}$ & 1.44 & 1.85 & $\mathrm{~K}_{2} \mathrm{O}$ & 0.01 \\
\hline $\mathrm{MnO}$ & 2.71 & 2.95 & 5.99 & 6.09 & $\mathrm{FeO}$ & 4.82 & 5.37 & $\mathrm{H}_{2} \mathrm{O}$ & 9.15 \\
\hline $\mathrm{MgO}$ & 0.12 & 0.10 & 9.10 & 0.11 & $\mathrm{MnO}$ & 4.20 & 2.24 & Sum & 98.99 \\
\hline $\mathrm{CaO}$ & 24.09 & 25.39 & 12.43 & 12.70 & $\mathrm{MgO}$ & 0.08 & 0.01 & & \\
\hline $\mathrm{Na}_{2} \mathrm{O}$ & 9.39 & 9.14 & 6.80 & 8.53 & $\mathrm{CaO}$ & 11.85 & 12.28 & Atoms & \\
\hline $\mathrm{F}$ & 8.16 & $8.49-$ & - & - & $\mathrm{Na}_{2} \mathrm{O}$ & 11.16 & 9.02 & $\mathrm{Si}$ & 2.987 \\
\hline Sum & 99.87 & 101.29 & 101.25 & 101.20 & $\mathrm{~K}_{2} \mathrm{O}$ & 0.26 & 0.25 & $\mathrm{Zr}$ & 1.008 \\
\hline$-\mathrm{O}=\mathrm{F}$ & 3.43 & 3.58 & 2.24 & 2.43 & $\mathrm{SrO}$ & 0.11 & 0.02 & $\mathrm{Ca}$ & 0.988 \\
\hline \multirow[t]{2}{*}{ Sum } & \multirow[t]{3}{*}{96.44} & \multirow[t]{3}{*}{97.71} & \multirow[t]{3}{*}{99.01} & \multirow[t]{3}{*}{98.77} & $\mathrm{La}_{2} \mathrm{O}_{3}$ & 0.40 & 0.78 & $\mathrm{Na}$ & 0.020 \\
\hline & & & & & $\mathrm{Ce}_{2} \mathrm{O}_{3}$ & 0.41 & 1.19 & K & 0.000 \\
\hline Atoms & & & & & $\mathrm{Cl}$ & 1.16 & 1.08 & Sum & 5.003 \\
\hline $\mathrm{Si}$ & 2.001 & 1.980 & 2.131 & 2.039 & $-\mathrm{O}=\mathrm{Cl}$ & 0.26 & 0.24 & & \\
\hline $\mathrm{Ti}$ & 0.368 & 0.386 & 0.185 & 0.217 & Sum & 98.59 & 96.23 & & \\
\hline $\mathrm{Zr}$ & 0.449 & 0.414 & 0.954 & 0.891 & $\mathrm{Si}$ & 25.369 & 25.371 & & \\
\hline $\mathrm{Nb}$ & 0.036 & 0.047 & 0.041 & 0.063 & $\mathrm{Al}$ & 0.060 & 0.076 & & \\
\hline $\mathrm{Fe}^{2+}$ & 0.051 & 0.034 & 0.163 & 0.156 & $\mathrm{Ti}$ & 0.154 & 0.052 & & \\
\hline $\mathrm{Mn}$ & 0.147 & 0.157 & 0.332 & 0.340 & $\mathrm{Zr}$ & 3.085 & 3.072 & & \\
\hline $\mathrm{Mg}$ & 0.012 & 0.010 & 0.009 & 0.011 & $\mathrm{Nb}$ & 0.331 & 0.429 & & \\
\hline $\mathrm{Ca}$ & 1.654 & 1.716 & 0.871 & 0.896 & $\mathrm{Fe}^{2+}$ & 2.046 & 2.317 & & \\
\hline $\mathrm{Na}$ & 1.167 & 1.120 & 0.862 & 1.090 & $\mathrm{Mn}$ & 1.805 & 0.970 & & \\
\hline Sum & 5.885 & 5.863 & 5.548 & 5.703 & $\mathrm{Mg}$ & 0.063 & 0.001 & & \\
\hline F & 1.654 & 1.695 & 1.103 & 1.201 & $\mathrm{Ca}$ & 6.443 & 6.757 & & \\
\hline $\mathrm{S} 1$ & 1.062 & 1.048 & 1.684 & 1.678 & $\mathrm{Na}$ & 10.981 & 9.038 & & \\
\hline \multirow[t]{6}{*}{$\mathrm{S} 2$} & 2.822 & 2.836 & 1.733 & 1.986 & $\mathrm{~K}$ & 0.168 & 0.158 & & \\
\hline & & & & & $\mathrm{Sr}$ & 0.033 & 0.001 & & \\
\hline & & & & & $\mathrm{La}$ & 0.076 & 0.185 & & \\
\hline & & & & & $\mathrm{Ce}$ & 0.077 & 0.283 & & \\
\hline & & & & & Sum & 50.693 & 48.719 & & \\
\hline & & & & & $\mathrm{Cl}$ & 1.002 & 0.943 & & \\
\hline
\end{tabular}
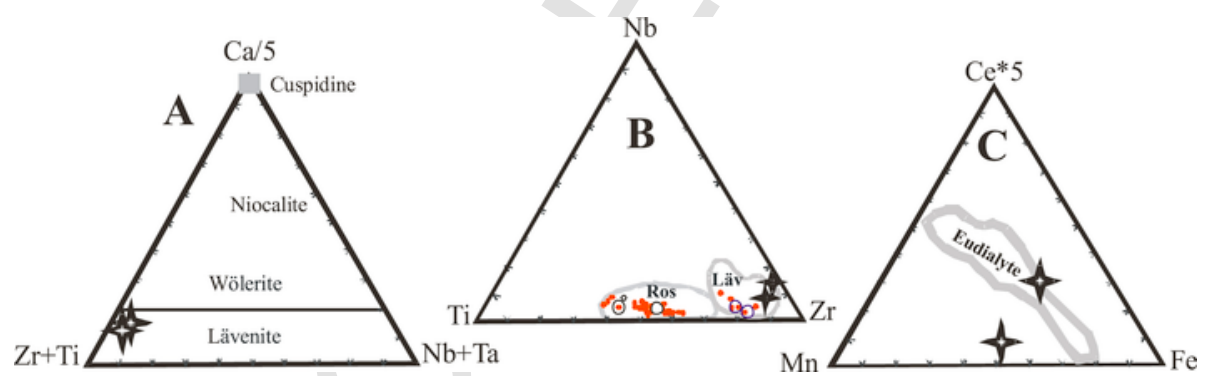

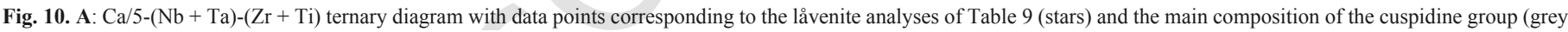

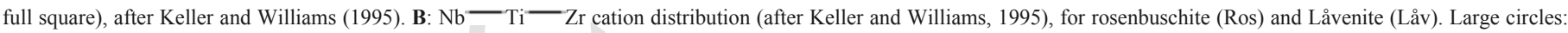

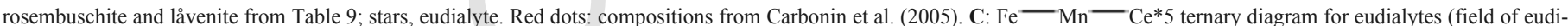
alyte from Sjöqvist et al., 2013). (For interpretation of the references to colour in this figure legend, the reader is referred to the web version of this article.) 

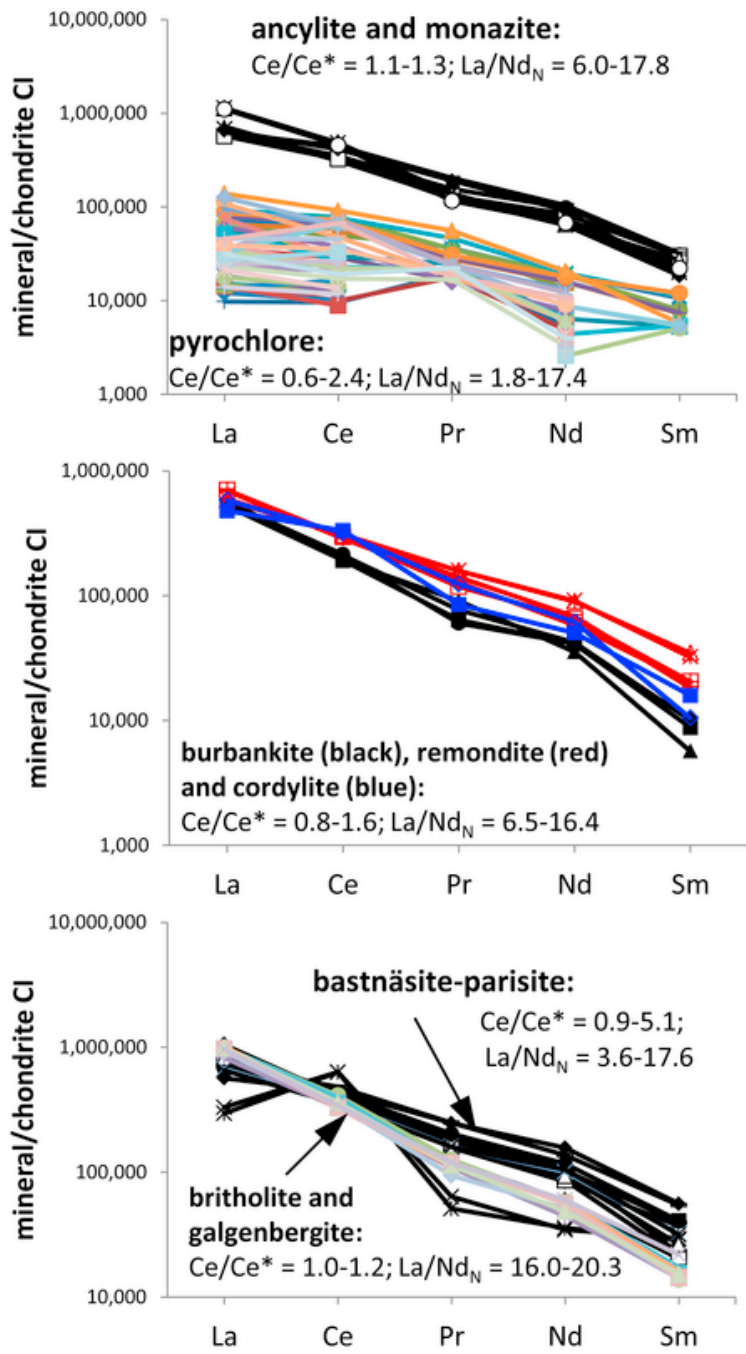

Fig. 11. LREE patterns of REE-bearing minerals normalized to chondrite CI (Barrat et al., 2012); $\mathrm{Ce} / \mathrm{Ce}^{*}=\mathrm{Ce} /(\mathrm{La} \cdot \mathrm{Pr})^{0.5}, \mathrm{La} / \mathrm{Nd}_{\mathrm{N}}=\mathrm{La} / \mathrm{Nd}$ (both normalized to chondrite CI).

\section{References}

Aksenov, S.M., Rastsvetaeva, R.K., Mitchell, R.H., Chakrabarty, A., 2014. Crystal structure of manganese-rich variety of eudialyte from Suchina hill, India, and manganese ordering in eudialyte group minerals. Crystallogr. Rep. 59, 146-154.

Alaimo, R., Censi, P., 1992. Quantitative determination of major, minor and trace elements on USGS rock standards by inductively coupled plasma mass spectrometry. At. Spectrom. 13, 113-119.

Amaral, G., 1984. Provincia Tapajós e Rio Branco. In: Almeida, F., F:A, Hasui, Y. (Eds.), O Précambriano do Brasil. Edgar Blücher Ltda, São Paulo, pp. 6-35.

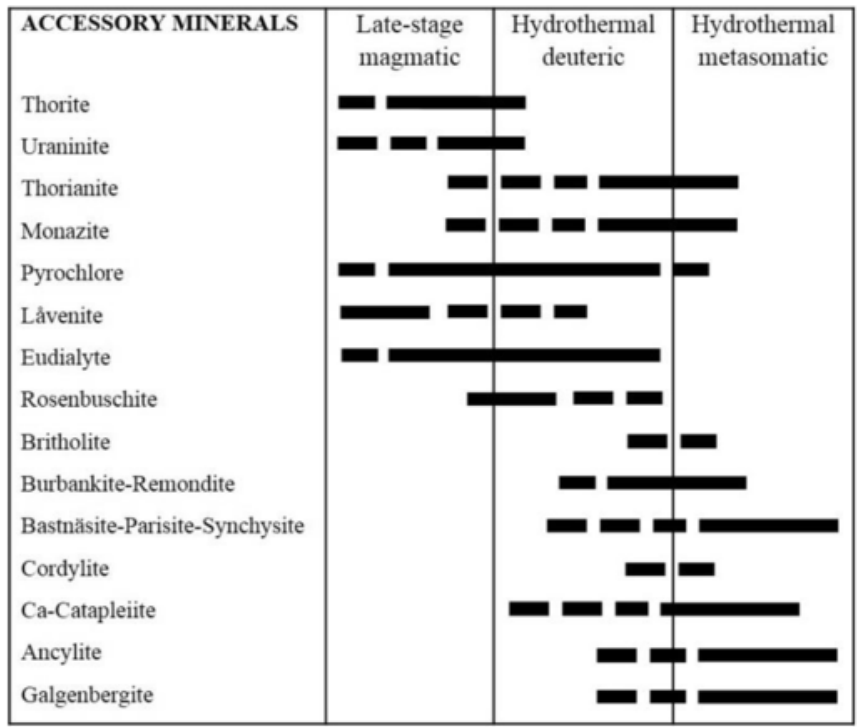

Fig. 12. Bar diagram showing the crystallization history of the accessory minerals in the nepheline syenites and phonolites of Cerro Boggiani agpaitic complex. The diagram roughly attributes each accessory mineral to one or more of the following phases of crystallization: (i) late-stage magmatic, (ii) hydrothermal deuteric $\left(\mathrm{H}_{2} \mathrm{O}\right.$-rich) and (iii) hydrothermal metasomatic of carbonatitic origin $\left(\mathrm{CO}_{2}\right.$-rich). Dashed lines represent low modal content and/or some uncertainty of attribution to the correspondent phase of crystallization

Andersen, T., 2014. REE mineral assemblages in igneous rocks: what can be learned from chemographic modelling?. In: Workshop on Accessory Minerals. Universiy of Warsaw, pp. 7-8.

Barrat, J.A., Zanda, B., Moynier, F., Bollinger, C., Liorzou, C., Bayon, G., 2012. Geochemistry of $\mathrm{CI}$ chondrites: major and trace elements, and $\mathrm{Cu}$ and $\mathrm{Zn}$ isotopes. Geochim. Cosmochim. Acta 83, 79-92.

Bastin, G.F., Van Loo, F.J.J., Heijligers, H.J.M., 1984. Evaluation and use of gaussian $\phi(\rho z)$ curves in quantitative electron probe microanalysis: a new optimization. X-Ray Spectrom. 13, 91-97.

Bellezza, M., Merlino, S., Perchiazzi, N., 2003. Chemical and structural study of the $\mathrm{Zr}$, Ti-disilicates in the venanzite from Pian di Celle, Umbria, Italy. In: Geoitalia 2003, $4^{\circ}$ Forum Italiano di Scieze della Terra, Bellaria. pp. 604-605.

Belovtiskaya, Y.V., Pekov, I.V., 2004. Genetic mineralogy of burbankite group. New Data Minerals 742 (39), 50-64. UDC 549.

Birkett, T.C., Miller, R.R., Roberts, A.C., Kariano, A.N., 1992. Zirconium bearing minerals of the Srange lake complex, Quebec, Labrador. Can. Mineral. 30, 191-205.

Carbonin, S., Liziero, F., Fuso, C., 2005. Mineral chemistry of accessory minerals in alkaline complexes from the Alto Paraguay province. In: Comin-Chiaramonti, P., Gomes, C.B. (Eds.), Mesozoic to Cenozoic Alkaline Magmatism in the Brazilian Platform. Edusp/Fapesp, São Paulo, pp. 149-158.

Castorina, F., Censi, P., Comin-Chiaramonti, P., Gomes, C.B., Piccirillo, E.M., Alcover Neto, A., Almeida, R.T., Speziale, S., Toledo, M.C., 1997. Geochemistry of carbonatites from eastern Paraguay and genetic relationships with potassicc magmatism: C, O, Sr and Nd isotopes. Mineral. Petrol. 61, 237-260.

Censi, P., Comin-Chiaramonti, P., DeMarchi, G., Longinelli, A., Orué, D., 1989. Geochemistry and C-O isotopes of the Chiriguelo carbonatite (north-eastern Paraguay) J. S. Am. Earth Sci. 3, 295-303.

Cesbron, F., Gilles, C., Pelisson, P., Saugues, J.C., 1988. La remondite-(Ce), un nouveau carbonate de terres rares de la famille de la burbankite. In: Comptes Rendus de l'Académie des Sciences Paris Série II, 307 pp. 915-920. 
Chakhmouradian, A.R., Mitchell, R.H., 1998. Lueshite, pyrochlore and monazite-(Ce) from apatite-dolomite carbonatite, Lesnaya Varaka complex, Kola Peninsula, Russia. Mineral. Mag. 62, 769-782.

Clavier, N., Podor, R., Dacheux, N., 2011. Crystal chemistry of the monazite structure J. Eur. Ceram. Soc. 31, 941-976.

Comin-Chiaramonti, P., De Min, A., Girardi, V.A.V., Gomes, C.B., 2014. Carbonatites and primary carbonates in the Rio Apa and Amambay regions, NE. Parag. Lithos 188, 84-96.

Comin-Chiaramonti, P., Gomes, C.B., Censi, P., Gasparon, M., Velázquez, V.F., 2005. Alkaline complexes from the Alto Paraguay province at the border of Brazil (Mato Grosso do Sul state) and Paraguay. In: Comin-Chiaramonti, P., Gomes, C.B. (Eds.), Mesozoic to Cenozoic Alkaline magmatism in the Brazilian Platform. Edusp/Fapesp, São Paulo, pp. 71-148.

Comin-Chiaramonti, P., Gomes, C.B., De Min, A., Ernesto, M., Gasparon, M., 2015. Magmatism along the high Paraguay River at the border of Brazil and Paraguay: a review and new constraints on emplacement ages. J. S. Am. Earth Sci. 58, 72-81.

Dal Negro, A., Rossi, G., Tazzoli, V., 1975. The crystal structure of ancyllite, $(\mathrm{REE})_{\mathrm{x}}(\mathrm{Ca}, \mathrm{Sr})_{2-\mathrm{x}}\left(\mathrm{CO}_{3}\right)_{2}(\mathrm{OH})_{\mathrm{x}}(2-\mathrm{x}) \mathrm{H}_{2} \mathrm{O}$. Am. Mineral. 60, 280-284.

Deer, W.A., Howie, R.A., Zussman, J., 1997. Disilicates and ringsilicates Rock-forming Minerals. vol. 1B. The Geological Society of London, 333.

De La Roche, H., Leterrier, P., Grandclaude, P., Marchal, M., 1980. A classification of volcanic and plutonic rocks using $\mathrm{R}_{1} \mathrm{R}_{2}$ diagram and major-element analyses. Its relationships with current nomenclature. Chem. Geol. 29, 183-210.

Drake, M.J., Weill, D.F., 1972. New rare element standeards for electron microprobe analysis. Chem. Geol. 10, 179-181.

Enrich, G.E.R., Ruberti, E., 2004. Química mineral de britholitas em nefelina microssienitos da suíte alcalina da Ilha Monte de Trigo (SP). In: XLII Congresso Brasileiro de Geologia, Araxá, 2004.

Enrich, G.E.R., Gomes, C.B., Ruberti, E., 2010. Química mineral de carbonatos de elementos terras raras em nefelina sienitos e fonólitos agpaíticos do maciço de Cerro Boggiani, Província Alto Paraguay, Paraguai. In: X Congresso de Geoquímica dos Países de Língua Portuguesa, Porto, 2010, Actas. pp. 223-227.

Enrich, G.E.R., Gomes, C.B., Ruberti, E., Azzone, R.G., 2011. Silicatos de zircônio do grupo da cuspidina-wöhlerita nas rochas vulcânicas agpaíticas do maciço alcalino de Cerro Boggiani, Paraguai. In: V Simpósio de Vulcanismo e Ambientes Associados, Cidade de Goiás, Anais, CD-ROM.

Enrich, G.E.R., Gomes, C.B., Ruberti, E., Azzone, R.G., 2012. Eudialitas do maciço alcalino de Cerro Boggiani, Paraguai: ocorrência e composição química. In: $46^{\circ}$ Congresso Brasileiro de Geologia, Santos, CD-ROM.

Förster, H.-J., 1999. The chemical composition of uraninite in Variscan granites of Erzgebirge, Germany. Mineral. Mag. 63, 239-252.

Gieré, R., 1996. Formation of rare earth minerals in hydrothermal systems. The Mineralogical Society Series 7. In: Jones, A.P., Wall, F., Williams, C.T. (Eds.), Rare Earth Minerals: Chemistry, Origin and Ore Deposits, Chapman \& Hall, London, pp. $105-150$

Giester, G., Ni, Y., Jarosch, D., Hughes, J.M., Rønsbo, J., Yang, Z., Zemann, J., 1998. Cordylite-(Ce): a crystal chemical investigation of material from four localities, including type material. Am. Mineral. 83, 178-184.

Gomes, C.B., Laurenzi, M.A., Censi, P., De Min, A., Velázquez, V.F., Comin-Chiaramonti, P., 1996. Alkaline magmatism from northern Paraguay (Alto Paraguay): a Permo-Triassic province. In: Comin-Chiaramonti, P., Gomes, C.B. (Eds.), Alkaline magmatism in Central-Eastern Paraguay. Relationships with Coeval Magmatism in Brazil. Edusp/Fapesp, São Paulo, pp. 223-230.

Haas, J.R., Shock, E.L., Sassani, D.C., 1995. Rare earth elements in hydrothermal system: estimates of standard partial molar thermodynamic properties of aqueous complexes of the rare earth elements at high pressures and temperatures. Geochim. Cosmochim. Acta 59, 4329-4350.

Harlov, D.E., Hetherington, C.J., 2010. Partial high-grade alteration of monazite using alkali-bearing fluids: experiment and nature. Am. Mineral. 95, 1105-1108.

Hogarth, D.D., 1989. Pyrochlore, apatite and amphibole: distinctive minerals in carbonatite. In: Bell, K. (Ed.), Carbonatites: Genesis and Evolution. Chapman and Hall, London, U.K, pp. 105-148.

Hogarth, D.D., Rushforth, P., McKorkell, R.H., 1988. The Blackburn carbonatites, near Ottawa, Ontario: dikes with fluidized emplacement. Can. Mineral. 26, 377-390.

Hogarth, D.D., Horne, J.E.T., 1989. Non-metamict uranoan pyrochlore and uranpyrochlore from tuff near Ndale, Fort Portal area, Uganda. Mineral. Mag. 53, 257-262.

Hornig-Kjarsgaard, I., 1998. Rare earth elements in sövitic carbonatites and their mineral phases. J. Petrol. 39 (11-12), 2105-2121.

Jarosevich, E.N., 2002. Electron microprobe standards, mineral standards, microbeam standards. Smithson. Microbeam Stand. J. Res. Natl. Inst. Stand. Technol. 107, 681-685.

Johnsen, O., Grice, G.D., 1999. The crystal chemistry of the eudyalite group. Can. Mineral. 37, 865-891.
Karup-Møller, S., Hansen, J.R., Sørensen, S., 2010. Eudialyte decomposition minerals with new hitherto undercribed phases from the Ilimaussaq complex, south Greenland. Bull. Geol. Soc. Den. 58, 75-88.

Keller, J., Williams, T.C., 1995. Niocalite and wöhlerite from alkaline and carbonatite rocks at Kaisertuhl, Germany. Mineral. Mag. 59, 561-566.

Khomyakov, A.P., 1995. Mineralogy of Hyperagpaitic Alkaline Rocks. Oxford Science Publications, 222.

Kogarko, L.N., 1987. Alkaline rocks of the eastern part of the Baltic shield (Kola peninsula). In: Fitton, J.G., Upton, B.G.J. (Eds.), Alkaline Igneous Rocks. Geological Society of London, Special Publication, 30. pp. 531-544.

Kogarko, L.N., Burnham, C., Shettle, D., 1977. Water regime in alkalic magmas. Geochem. Int. 14, 1-8.

Kogarko, L.N., Ryabchikov, I.D., Sørensen, H., 1974. Liquid fractionation. In: Sørensen, H. (Ed.), The Alkaline Rocks. John Wiley, London, pp. 488-500.

Le Maitre, R.W., 1989. A Classification of Igneous Rocks and Glossary of Terms. Blackwell Science Publication, Oxford, 193.

Lemarão, C.N., Dall'Agnol, R., Lafon, J.-M., Lima, E.F., 2002. Geology, geochemistry and $\mathrm{Pb}-\mathrm{Pb}$ zircon geochronology of the paleoproterozoic magmatism of Vila Riozinho, Tapajos province, Amazonian Craton, Brazil. Precambr. Res. 119, 189-223.

Lumpkin, G.R., Ewing, R.C., 1995. Geochemical alteration of pyrochlore group minerals; pyrochlore subgroup. Am. Mineral. 80, 732-743.

Mahato, A.C., Ren, M., Chakrabarti, A., Sen, A.K., Rajesh, H.M., Shindo, K., 2013. Reconstruction of magmatic to deuteric stages of the eudyalite-bearing Sushina syenite gneiss, western Bengala, India. J. Ind. Geol. Congr. 5, 77-93.

Mellini, M., 1981. Refinement of the crystal structure of låvenite. Tschermaks Mineral. Petrogr. Mittl. 28, 99-112.

Merlino, S., Pasero, S., Bellezza, M., Pushcharovsky, D.Y., Gobecchia, E.R., Zubkova, N.V., Pehov, I.V., 2004. Crystal structure of calcium catapleite. Can. Mineral. 42, 1037-1045.

Mills, S.J., Kartashov, P., Kampf, A.R., Konev, A.A., Koneva, A.A., Raudsepp, M., 2012. Cordylite, a new mineral from the Biraya Fe-REE deposit, Irkutsk, Russia. Can. Mineral. 50, 1281-1290.

Mitchell, R.H., 2015. Primary and secondary niobium mineral deposits associated with carbonatites. Ore Geol. Rev. 64, 626-641.

Moine, B., Ramambazafy, A., Rakotondrazafy, M., Ravolomiandrinarivo, B., Cuney, M., Parseval, P., 1998. The role of fluor-rich fluids in the formation of the thorianite and sapphire deposits from SE Madagascar. In: Goldschmidt Conference, Toulouse. pp. 999-1000.

Niet, Y., Hughes, J.M., Mariano, A.N., 1995. Crystal chemistry of monazite and xenotime structures. Am. Mineral. 80, 21-26.

Oberti, R., Ottolini, L., Della Ventura, G., Parodi, G.C., 2001. On the symmetry and crystal chemistry of britholite: new structural and microanaytical data. Am. Mineral. 86, 1066-1075.

Pekov, I.V., Chukanov, N.V., Kononkova, N.N., Zadov, A.E., Belovitskaya, Y.V., 2000. Remondite-(La), $\mathrm{Na}_{3}(\mathrm{La}, \mathrm{Ce}, \mathrm{Ca})_{3}\left(\mathrm{CO}_{3}\right)_{5}$ - a new mineral of the burbankite family from the Khibina Massif, Kola peninsula. Zap. Vserossiyskogo Mineral. Obshchestva 129 (1), 53-60 (in Russian).

Pekov, I.V., Pasero, M., Yaskovskaya, A.N., Chukanov, N.V., Yu Puschcharovsky, D., Merlino, S., Zubkova, N.V., Kononkova, N.N., Men'shikov, Y.P., Zadov, A.E., 2007. Fluorbritholite, $(\mathrm{Ca}, \mathrm{REE})_{5}\left[(\mathrm{Si}, \mathrm{P}) \mathrm{O}_{4}\right]_{3} \mathrm{~F}$, a new mineral: description and crystal chemistry. Eur. J. Mineral. 19, 95-102.

Pekov, I.V., Petersen, O.V., Voloshin, A.V., 1997. Calcio-ancylite-(Ce) from Ilimaussaq and Narssarssuk, Greenland, Kola peninsula and Polar Urals, Russia; ancylite-(Ce)-calcioAncylite-(Ce) an isomorphous series. Neues Jahrb. Mineral. Abh. 171, 309-322.

Putzer, H., Van den Bomm, G., 1962. Über einige Vorkommen von Alkaligesteinen in Paraguay. Geol. Jahrb. 79, 423-443.

Ridolfi, F., Renzulli, A., Santi, P., Upton, B.G.J., 2003. Evolutionary stages of crystallization of weakly peralkaline syenites: evidence from ejecta in the plinian deposits of Agua de Pau volcano (São Miguel, Azores Islands). Mineral. Mag. 67, 749-767.

Ridolfi, F., Renzulli, A., Macdonald, R., Upton, B.G.J., 2006. Peralkaline syenite autoliths from Kilombe volcano, Kenya Rift valley: evidence for subvolcanic interaction with carbonatitic fluids. Lithos 91, 373-392.

Roeder, P.L., 1985. Electron-microprobe analysis of minerals for rare earth elements use of calculate peak-overlap corrections. Can. Mineral. 23, 263-271.

Ruberti, E., Enrich, G.E.R., Gomes, C.B., Comin-Chiaramonti, P., 2008. Hydrothermal REE fluorcarbonate mineralization at Barra do Itapirapuã, a multiple stockwork carbonatite, southern Brazil. Can. Mineral. 46, 1361-1374.

Sjöqvist, A.S.L., Cornell, David H., Andersen, T., Erambert, M., Ek, M., Leijd, M., 2013. Three compositional varieties of rare-earth element ore: eudialyte-group minerals from the Norra Kårr alkaline complex, southern Sweden. Minerals 3, 94-120.

Smith, M.P., Henderson, P., Campbell, L.S., 2000. Fractionation of the REE during hydrothermal processes: constraints from the Bayan Obo Fe-REE-Nb deposit, Inner Mongolia, China. Geochim. Cosmochim. Acta 64, 3141-3160. 
Soares, J.E., Berrocal, J.U., Fuck, R.A., Mooney, W.D., Ventura, D.B.R., 2006. Seismic characteristics of central Brazil crust and upper mantle; a deep seismic refraction study. J. Geophys. Res. 111 (B12302), 1-31.

Sørensen, H., 1997. The agpaitic rocks, an overview. Mineral. Mag. 61, 485-498.

Speziale, S., Censi, P., Comin-Chiaramonti, P., Ruberti, E., Gomes, C.B., 1997. Oxygen and carbon isotopes in the Barra do Itapirapuá and Mato Preto carbonatites (southern Brazil). Mineral. Petrogr. Acta 40, 137-157.

Stoppa, F., Schiazza, M., 2014. Extreme chemical conditions of crystallisations of Umbrian Melilitolites and wealth of rare, late stage/hydrothermal minerals. Central Eur. J. Geosci. 6 (4), 549-564.

Sun, S.S., McDonough, W.F., 1989. Chemical and isotopic systematics of oceanic basalts. In: Saunders, D., Norry, M.J. (Eds.), Magmatism in the Ocean Basins. Geological Society Special Publication, 42. pp. 313-345.

Toledo, M.C.M., Pereira, V.P., 2003. Ocorência e variabilitade da comosição dos fosfatos do grupo da monazita em carbonatitos. Pesqui. Geociênc. 30, 83-95.

Torro, L., Villanova, C., Castillo, M., Campeny, M., Gonçalves, A.O., Melgarejo, J.C., 2012. Niobium and rare earth minerals from the Virilundo carbonatite, Namibia. Mineral. Mag. 76, 393-409.
Wagner, C., Mokhtari, A., Deloule, E., Chabaux, F., 2003. Carbonatite and alkaline magmatism in Taouririt (Morocco): petrological, geochemical and $\mathrm{Sr}-\mathrm{Nd}$ isotope characteristics. J. Petrol. 44 (5), 937-965.

Walter, F., Bojar, H.-P., Hollerer, C.E., Mereiter, K., 2013. The crystal structure of galgenbergite-(Ce), $\mathrm{CaCe}_{2}\left(\mathrm{CO}_{3}\right)_{4} \bullet \mathrm{H}_{2} \mathrm{O}$. Mineral. Petrol. 107, 189-199.

Williams, M.L., Jercinovic, M.J., Hetherington, C.J., 2007. Microprobe monazite geochronology: understanding geological processes by integrating compositions and geochronology. Annu. Rev. Earth Planet. Sci. 35, 137-175.

Woolley, A.R., Platt, R.G., 1988. The peralkaline nepheline syenite of the Junguni intrusion, Chilwa province, Malawi. Mineral. Mag. 52, 425-433.

Zaitsev, A.N., Wall, F., LeBas, M.J., 1998. REE-Sr-Ba minerals from the Khibina carbonatites, Kola Peninsula, Russia: their mineralogy, paragenesis and evolution. Mineral. Mag. 62, 225-250.

Zurevinski, S.E., Mitchell, R.H., 2004. Extreme compositional variation of pyrochlore-group minerals at the Oka carbonatite complex, Quebec: evidence of magma mixing?. Can. Mineral. 42, 1159-1168. 